\title{
Ciliary Neurotrophic Factor Receptor Regulation of Adult Forebrain Neurogenesis
}

\author{
Nancy Lee, ${ }^{1}$ Myra K. Batt, ${ }^{1}$ Brigitte A. Cronier, ${ }^{1}$ Michele C. Jackson, ${ }^{1}$ Jennifer L. Bruno Garza, ${ }^{1}$ Dennis S. Trinh, ${ }^{1}$ \\ Carter 0. Mason, ${ }^{1}$ Rachel P. Spearry, ${ }^{1}$ Shayon Bhattacharya, ${ }^{1}$ Rachel Robitz, ${ }^{1}$ Masato Nakafuku, ${ }^{2}$ \\ and A. John MacLennan ${ }^{1}$ \\ ${ }^{1}$ Department of Molecular \& Cellular Physiology, University of Cincinnati, Cincinnati, Ohio 45267, and 2Division of Developmental Biology, Cincinnati \\ Children's Hospital Research Foundation, Cincinnati, Ohio 45229
}

Appropriately targeted manipulation of endogenous neural stem progenitor (NSP) cells may contribute to therapies for trauma, stroke, and neurodegenerative disease. A prerequisite to such therapies is a better understanding of the mechanisms regulating adult NSP cells in vivo. Indirect data suggest that endogenous ciliary neurotrophic factor (CNTF) receptor signaling may inhibit neuronal differentiation of NSP cells. We challenged subventricular zone (SVZ) cells in vivo with low concentrations of CNTF to anatomically characterize cells containing functional CNTF receptors. We found that type B "stem" cells are highly responsive, whereas type C "transit-amplifying" cells and type A neuroblasts are remarkably unresponsive, as are $\mathrm{GFAP}^{+}$astrocytes found outside the SVZ. CNTF was identified in a subset of type B cells that label with acute BrdU administration. Disruption of in vivo CNTF receptor signaling in SVZ NSP cells, with a "floxed" CNTF receptor $\alpha(\mathrm{CNTFR} \alpha)$ mouse line and a gene construct driving Cre recombinase (Cre) expression in NSP cells, led to increases in SVZ-associated neuroblasts and new olfactory bulb neurons, as well as a neuron subtype-specific, adult-onset increase in olfactory bulb neuron populations. Adult-onset receptor disruption in SVZ NSP cells with a recombinant adeno-associated virus (AAV-Cre) also led to increased neurogenesis. However, the maintenance of type B cell populations was apparently unaffected by the receptor disruption. Together, the data suggest that endogenous CNTF receptor signaling in type B stem cells inhibits adult neurogenesis, and further suggest that the regulation may occur in a neuron subtype-specific manner.

\section{Introduction}

Under normal conditions, adult neurogenesis derives mostly from neural stem progenitor (NSP) cells located in the subventricular zone (SVZ) around the lateral ventricle and the subgranular layer of the hippocampus (Zhao et al., 2008). Research suggests that, if the endogenous mechanisms regulating these cells in vivo were sufficiently understood, it may become possible to manipulate the cells to combat the neurodegenerative effects of trauma, stroke, disease, and aging (Taupin, 2007).

CNTFR $\alpha$ is the essential ligand binding subunit of the CNTF receptor, which is composed of $\operatorname{CNTFR} \alpha$, leukemia inhibitory factor receptor $\beta$ (LIFR $\beta$ ), and gp130 (Ip et al., 1992; 1993; Davis et al., 1993). CNTF (Davis et al., 1991) and CLC/CLF (Elson et al., 2000) have been identified as ligands. Several studies indirectly suggest that endogenous CNTF receptor signaling regulates SVZ neurogenesis. Some of these studies suggest that it promotes the

Received July 16, 2012; revised Nov. 29, 2012; accepted Nov. 30, 2012.

Author contributions: N.L., M.N., and A.J.M. designed research;N.L., M.K.B., B.A.C., M.C.J., J.L.B.G., D.S.T., C.O.M., R.P.S., S.B., and R.R. performed research; A.J.M. analyzed data; M.N. and A.J.M. wrote the paper.

This work was supported by National Institutes of Health Grant NS066051 to A.J.M. We thank Dr. Albee Messing for the hGFAP-Cre mice, Dr. Sergei Zolotukhin for the AAV-Cre, Dr. Melissa Colbert for the CAG-CAT-EGFP reporter mice, Dr. Jane Johnson for the Ascl1 antibody, and Glenn Doerman for assistance with the figures.

The authors declare no competing financial interests.

Correspondence should be addressed to Dr. A. John MacLennan, Department of Molecular \& Cellular Physiology, University of Cincinnati, 231 Albert Sabin Way, Cincinnati, OH 45267-0576. E-mail: john.maclen@uc.edu.

DOI:10.1523/JNEUROSCI.3386-12.2013

Copyright $\odot 2013$ the authors $\quad 0270-6474 / 13 / 331241-18 \$ 15.00 / 0$ self-renewal of adult SVZ NSP cells and inhibits their neuronal differentiation. CNTF and LIF have such effects on cultured embryonic and adult forebrain SVZ NSP cells (Shimazaki et al., 2001; Pitman et al., 2004; Bauer and Patterson, 2006; Muller et al., 2009). Adult LIFR $\beta^{+/-}$mice, with partial decreases in both CNTF and LIF receptors, display a reduction in SVZ NSP cells, measured in vitro (Shimazaki et al., 2001). Exogenous LIF increases NSP cells and decreases SVZ derived neuroblasts and associated neurogenesis in vivo (Bauer and Patterson, 2006). However, none of these studies directly addresses the role of endogenous CNTF receptor signaling, nor do they distinguish between LIF receptor and CNTF receptor effects of the exogenous ligands used because LIF activates both receptor types (Ip et al., 1992), and so can CNTF at the concentrations used (Saggio et al., 1995). Moreover, in apparent conflict with the above results, exogenous CNTF has been reported to increase SVZ neurogenesis in vivo (Emsley and Hagg, 2003) and unconditional genetic disruption of CNTF, with potential developmental effects, decreases some markers of SVZ neurogenesis (Yang et al., 2008).

Therefore, the literature indirectly suggests that endogenous CNTF receptor signaling may regulate adult SVZ neurogenesis and NSP cell maintenance in some undetermined manner. We report that, in the adult SVZ, functional CNTF receptors are confined to type B "stem" cells. To directly study their function, we developed Cre/loxP approaches to conditionally disrupt the CNTFR $\alpha$ gene, which is required for all forms of endogenous CNTF receptor signaling, regardless of the ligands or signaling 
pathways involved (Davis et al., 1993; Elson et al., 2000) but is not required for LIF receptor signaling (Ip et al., 1992). Our data indicate that disruption of SVZ CNTF receptors leads to increases in SVZ derived neuroblasts and olfactory bulb neurogenesis, with no detected effect on the maintenance of type B stem cells. Moreover, the effects are restricted to specific classes of olfactory bulb neurons. Finally, adult-initiated $\operatorname{CNTFR} \alpha$ disruption with an AAV-Cre vector similarly led to increased neurogenesis, indicating that endogenous CNTF receptor signaling in adult-type B stem cells regulates neurogenesis independent of developmental effects.

\section{Materials and Methods}

General procedures and mice

We have previously described our floxed CNTFR $\alpha$ mice (Lee et al., 2008). The CAG-CAT-EGFP reporter mice (Nakamura et al., 2006) and hGFAP-Cre mice (Zhou et al., 2001) were generous gifts from Dr. Melissa Colbert, National Institutes of Health and Dr. Albee Messing, University of Wisconsin-Madison, respectively. ROSA26 mice (Soriano, 1999) were obtained from The Jackson Laboratory.

For all procedures, age-matched (generally littermate) knock-outcontrol pairs of mice were processed in parallel from any surgery through immunohistochemistry and image analysis by individuals kept blind to genotype. This pairing approach controlled for many potential sources of variability, including in utero and postnatal environments, variation in genetic background, age, and any variability in reagents. Therefore, the quantitative results were analyzed with appropriate paired tests (paired $t$ test or 2-way ANOVA with knock-out vs control as a "matched/within" variable).

With regard to descriptive statistics, for each knock-out/control pair of mice, a knock-out/control ratio was calculated to best characterize the effect in each individual knock-out mouse by comparing it with its most appropriate control (its control pair). These values were multiplied by 100 to obtain percentage values. For each experiment, the resulting values were then averaged across all the knock-out-control pairs in the experiment to obtain a mean reflecting the average knock-out value in percentage relative to controls.

FlxCNTFR $\alpha^{+/+}$and flxCNTFR $\alpha^{-1-}$ mice were generated by flxCNTFR $\alpha^{+/-} \times$flxCNTFR $\alpha^{+/-}$breeding. Other gene constructs were bred as heterozygote $\times$ wild-type to control for gene dosage. Cre recombinase (Cre) expressing flxCNTFR $\alpha^{-/-}$mice (i.e., wild-type at the CNTFR $\alpha$ locus; generally littermates of the floxed experimental mice) served as primary controls but were not distinguishable from flxCNTFR $\alpha^{+/+}$and flxCNTFR $\alpha^{-1-}$ mice without Cre, and flxCNTFR $\alpha^{+/-}$mice expressing Cre. All gene constructs were backcrossed at least 5 generations onto a common 129/SvEvBrd background. Genotyping was by PCR analysis of tail biopsy derived DNA. Animal procedures were approved by the University of Cincinnati Institutional Animal Care and Use Committee in accordance with National Institutes of Health guidelines.

\section{Anatomical procedures}

Mice were overdosed with avertin $(20 \mathrm{mg} / \mathrm{ml}$; intraperitoneal) and perfused with saline followed by $4 \%$ paraformaldehyde. Brains were postfixed in the same solution overnight at $4^{\circ} \mathrm{C}$ and cryoprotected in $30 \%$ sucrose with $2.5 \mathrm{~mm}$ sodium azide for at least $48 \mathrm{~h}$ before sectioning. Twenty micron coronal, cryostat sections were slide-mounted on gelatin-coated slides or processed free floating using standard Xgal histology methods or previously described immunohistochemistry procedures (MacLennan et al., 1996).

Primary antibodies. Antibodies are as follows: the previously characterized anti-CNTFR $\alpha$ antiserum "3X" (MacLennan et al., 1996), goat anti-rat CNTF, goat anti-rat CNTFR $\alpha$, and rabbit anti-human/mouse caspase 3 active (R\&D Systems), rabbit anti-calbindin D-28K, goat anticalretinin, rat anti-tyrosine hydroxylase, chicken anti-green fluorescent protein and mouse anti-GFAP (Millipore), mouse anti-rat PSA-NCAM (Developmental Studies Hybridoma Bank), goat anti- $\beta$ galactosidase (Biogenesis), rat anti-BrdU (AbD Serotec), rabbit anti-pSTAT3 (New
England Biolabs), and guinea pig anti-Ascl1 (Dr. Jane Johnson, University of Texas Southwestern).

Primary antibodies were visualized with either an elite ABC enzymatic amplification kit (Vector Laboratories) combined with a cyanine-3 tyramide TSA kit (PerkinElmer) or with secondary antibodies directly conjugated to AlexaFluor-488, AlexaFluor-594 (Invitrogen), CY2, CY3, CY5, FITC, or DyLight 488 (Jackson ImmunoResearch Laboratories).

Images were captured with either a 12 megapixel DXM1200 camera and Nikon E800 microscope or a Zeiss LSM-510 confocal microscope. All multilabeling conclusions were based on 3D reconstruction with the Zeiss LSM-510 confocal microscope and LSM Browser software. For analysis of BrdU retaining/GFAP ${ }^{+}$cells in the dorsal, septal/medial SVZ, every sixth $20 \mu \mathrm{m}$, coronal section throughout the SVZ was processed for GFAP/BrdU immunohistochemistry. For all sections between rostralcaudal levels corresponding to plates F0.9 and F0.0 of Slotnick and Leonard (1975), a stack of 10 overlapping ( $0.83 \mu \mathrm{m}$ interval), $1.7 \mu \mathrm{m}$ optical slices was captured from the most dorsal $330 \mu \mathrm{m}$ of the septal SVZ, starting immediately ventral to the corpus callosum. LSM Browser software was used to identify $\mathrm{GFAP}^{+} / \mathrm{BrdU}^{+}$cells in the SVZ with three or fewer primary processes (typically present in a distinct "line" of cells). The software was also used to confirm in 3D that the cells were doublelabeled. BrdU-retaining cells in lateral SVZ regions were counted in the same sections used for the medial/septal SVZ analysis. Acutely labeled BrdU cells in the entire SVZ were quantified in every sixth $20 \mu \mathrm{m}$ coronal section between rostral-caudal levels corresponding to plates F0.9 and F0.0 of Slotnick and Leonard (1975).

For counting of $\mathrm{BrdU}^{+}$periglomerular (PG) and granule layer (GL) neurons of the olfactory bulb, every sixth $20 \mu \mathrm{m}$ coronal section from the start of the internal granular layer to the start of the accessory olfactory bulb was processed, and all labeled cells from throughout the complete glomerular layer and granule layer were counted in each section. The same procedure was used to count $\mathrm{Xgal}^{+} \mathrm{PG}$ and GL neurons after $\mathrm{AAV}$-Cre and to count individual $\mathrm{PG}$ neuron subtypes (i.e., $\mathrm{CB}^{+}, \mathrm{CR}^{+}$, and $\mathrm{TH}^{+}$cells). For counting of rostral migratory stream (RMS) PSA$\mathrm{NCAM}^{+}$cells, every fourth section from beginning to end of the accessory olfactory bulb was processed and all labeled RMS cells were counted in each section.

\section{Injections and surgery}

BrdU injections. BrdU was dissolved in sterile saline at $15 \mathrm{mg} / \mathrm{ml}, \mathrm{pH}$ adjusted to $7.2-7.5$, and filter sterilized through a $0.45 \mu \mathrm{m}$ filter. Mice were either intraperitoneally injected at $150 \mathrm{mg} / \mathrm{kg}$ twice per day for 2 days and perfused 1 month later for identification of long-term proliferative ("BrdU retaining") SVZ residents and newly generated olfactory bulb neurons, or injected at $120 \mathrm{mg} / \mathrm{kg}$ five times at $2 \mathrm{~h}$ intervals with the last occurring $0.5 \mathrm{~h}$ before perfusion for identification of all proliferating SVZ cells.

$A A V$-Cre injection. The AAV-Cre was a kind gift from Dr. Sergei Zolotukhin, University of Florida. Its construction and characterization have been previously described (Lee et al., 2008). For administration of AAV-Cre, mice were anesthetized with ketamine/xylazine $(100 \mathrm{mg} / \mathrm{kg})$ and received aseptic, stereotaxic injections of AAV-Cre lateral to the SVZ (coordinates from bregma: $\mathrm{AP}+1.0, \mathrm{ML} \pm 1.0, \mathrm{DV}-1.9,-2.1 ; \mathrm{AP}+0.5$, $\mathrm{ML} \pm 1.3, \mathrm{DV}-1.5,-1.7$; $\mathrm{AP}+0.0, \mathrm{ML} \pm 1.3$, DV $-1.2,-1.4)$. A 33 gauge Hamilton needle was used to inject $1.5 \times 10^{7}$ infectious particles of $\mathrm{AAV}-\mathrm{Cre} / 6 \mu \mathrm{l}$ of PBS, distributed as six, $1 \mu \mathrm{l}$ injections, at a rate of 0.25 $\mu \mathrm{l} / \mathrm{min}$ (with a $1 \mathrm{~min}$ wait interval between each $0.25 \mu \mathrm{l}$ injected and a 10 min wait before needle removal).

CNTF injection and PSTAT3 assay. Mice were injected with $2 \mu \mathrm{l}$ of 0.5 $\mathrm{ng} / \mu \mathrm{l}$ recombinant rat $\mathrm{CNTF}$ (PeproTech) at $4 \mathrm{~min} /$ injection into two sites lateral to the SVZ (AP + 1.0, ML + 1.0, DV - 2.0; $\mathrm{AP}+0.5, \mathrm{ML}+1.3$, DV -1.6). The contralateral side received identical injections of the vehicle, saline. The mice were perfused $15 \mathrm{~min}$ after injection. Tyr705phosphorylated STAT3 (pSTAT3) was immunohistochemically localized as previously described (MacLennan et al., 2000). 


\section{Results}

\section{Cell type-specific distribution of functional CNTF receptors} in the adult SVZ

The adult SVZ has been reported to express CNTFR $\alpha$ (Emsley and Hagg, 2003; Enwere et al., 2004). However, CNTFR $\alpha$ expression does not necessarily indicate the presence of functional CNTF receptors given that: (1) LIFR $\beta$ and gp130 are also required to form a functional receptor complex; and (2) surprisingly, in most cell types throughout the brain expressing all three receptor subunits, the receptor responses are, under normal conditions, tonically blocked in vivo (MacLennan et al., 2000).

We have previously developed an assay to identify cells with functional CNTF receptors in vivo. Small quantities of CNTF are stereotaxically injected, and receptor activity is identified through immunohistochemical localization of Tyr705phosphorylated STAT3 (pSTAT3) with an extensively characterized antibody (MacLennan et al., 2000). The predominant form of CNTF receptor signaling involves this critical phosphorylation (Ip and Yancopoulos, 1996). The assay has been characterized with antibody preadsorption, receptor antagonism, and administration of growth factors signaling through pSTAT3 and non-pSTAT3 pathways (MacLennan et al., 2000). In addition, the CNTFR $\alpha$-dependent nature of the response in the SVZ (see below) further testifies to the validity of the procedure. In a previous survey of the brain, we found that all classes of motor neurons display a dramatic pSTAT3 response, whereas all other cells tested (which did not include the SVZ) fail to respond to even much higher CNTF concentrations (MacLennan et al., 2000), in an interesting parallel to the motor neuron-specific effects reported for unconditional CNTFR $\alpha$ knock-out mice (DeChiara et al., 1995).

To examine the SVZ, we injected 2- to 3-month-old wild-type mice with $2 \mu \mathrm{l}$ of $0.5 \mathrm{ng} / \mu \mathrm{l}$ CNTF into two sites adjacent to the SVZ (see Materials and Methods). The contralateral side received identical injections of vehicle. The mice were perfused $15 \mathrm{~min}$ after injection. We chose this early time point because: (1) in vitro work indicates that CNTF receptor activation leads to maximum STAT3 phosphorylation by 15 min (Boulton et al., 1995); (2) by examining responses this early, potential longer-term CNTFinduced changes and/or potential longer term responses evoked by stereotaxic needle injection, are avoided; and (3) our previous work with this assay indicated that $15 \mathrm{~min}$ is the time of maximal CNTF-induced pSTAT3 response in vivo (MacLennan et al., 2000).

Immunohistochemistry consistently revealed a low level of SVZ pSTAT3 on the vehicle-injected side (Fig. 1B) that was not seen in no primary antibody controls. Therefore, it likely reflects endogenous activity of all STAT3-based receptors in the SVZ. In contrast, CNTF injections would be expected to simultaneously and maximally activate cells containing functional CNTF receptors, thereby producing a much bigger response. In agreement, the CNTF-injected side consistently displayed a large increase in pSTAT3 confined to cells in and adjacent to the SVZ (Fig. 1A), indicating that the adult SVZ contains cells with functional CNTF receptors. The lack of response in neurons and glia in the striatum and neocortical parenchyma is consistent with our previous survey (MacLennan et al., 2000).

The fact that these pSTAT3 responses are CNTF-induced, and not seen after vehicle injection involving the same injectionrelated trauma, indicates that they are not injury responses. In addition, two independent lines of evidence each demonstrate that the CNTF-induced pSTAT3 responses result from CNTF activation of CNTF receptors. First, we have shown in the previous development of this pSTAT3 assay that the CNTF concentration used here activates only CNTF receptors in that the pSTAT3 responses are completely blocked by a well-characterized, specific CNTF receptor antagonist (MacLennan et al., 2000). Second, the CNTF-induced pSTAT3 responses in the SVZ are blocked by CNTFR $\alpha$ gene disruption (see below), which specifically disrupts CNTF receptor signaling.

We next used this assay to identify the SVZ cell types containing functional CNTF receptors. The SVZ contains slowly proliferating, self-renewing, GFAP-expressing, multipotent "stem" cells (also referred to as type B cells) (Alvarez-Buylla et al., 2001; Alvarez-Buylla and Garcia-Verdugo, 2002). Type B cell progeny include rapidly proliferating "transit-amplifying type C" progenitor cells, which are relatively short-lived precursors to SVZ neuroblasts ("type A" cells) (Alvarez-Buylla et al., 2001; Alvarez-Buylla and Garcia-Verdugo, 2002). The type A cells proliferate and simultaneously migrate via the RMS to the olfactory bulb where they differentiate into GL and PG interneurons (Altman and Das, 1966; Luskin, 1993; Lois and Alvarez-Buylla, 1994; Alvarez-Buylla and Garcia-Verdugo, 2002; Petreanu and Alvarez-Buylla, 2002). Essentially all of the CNTF-responsive SVZ cells are GFAP ${ }^{+}$(Figs. $1 C-K$ and $2 A-G$ ), the only caveat being that, in some SVZ regions in which the GFAP ${ }^{+}$cells display weak soma labeling and intertwined processes, it is not possible to definitively identify all responsive cells as GFAP ${ }^{+}$. Similarly, it appears that all $\mathrm{GFAP}^{+}$cells are responsive. The response was confined to those cells in and adjacent to the SVZ but was not restricted to any SVZ subregion, being seen in the complete rostral-caudal and dorsal-ventral aspects of the SVZ (e.g., Fig. $1 C-K$; see Fig. 5 control sections below). Responsive $\mathrm{GFAP}^{+}$cells were also observed in the RMS (Fig. $1 I, K$ ), which has been found to be another source of adult neurogenesis (Hack et al., 2005).

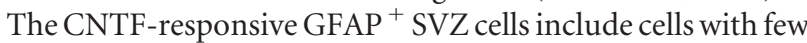
primary processes (Fig. $1 F-H$ ), a characteristic of type B cells involved in in vivo adult SVZ neurogenesis (Garcia et al., 2004). Moreover, BrdU injection a month before CNTF challenge indicated that at least some of the CNTF-responsive $\mathrm{GFAP}^{+}$cells are also $\mathrm{BrdU}^{+}$(Fig. 2D-G), and consequently very likely type B cells (Garcia et al., 2004). Notably, when CNTF injections were more distant from most of the SVZ and much closer to nonresponsive $\mathrm{GFAP}^{+}$cells in the striatum, the response was still confined to cells in and adjacent to the SVZ (Fig. $2 A-C$ ). Our motor neuron studies with this assay indicate, as one would expect, that motor neurons closer to the injection site receive higher CNTF concentrations in that they invariably respond most strongly (MacLennan et al., 2000). Therefore, the nonresponsive GFAP ${ }^{+}$astrocytes in the striatum near the injection site are clearly distinguishable from the GFAP ${ }^{+}$SVZ cells with regard to functional CNTF receptors. These data also further dissociate the CNTF-induced pSTAT3 response observed in the SVZ cells from trauma associated with the injection, in that those non-SVZ GFAP ${ }^{+}$cells closest to the trauma do not display the response whereas relatively distant SVZ GFAP ${ }^{+}$cells do respond.

In striking contrast to the pSTAT3 responses of the GFAP ${ }^{+}$ SVZ cells, none of the SVZ cells positive for the type A cell neuroblast marker PSA-NCAM displayed a pSTAT3 response (Fig. $2 H, I)$. Although type $\mathrm{C}$ cells are difficult to unambiguously identify, we found that almost all Ascl1 ${ }^{+}$SVZ cells fail to display a pSTAT3 response (Fig. $2 J-L$ ). Given that this marker labels the relatively abundant type $\mathrm{C}$ cells and rare active type B cells (Kim et al., 2011), the rare Ascl1 ${ }^{+}$cells displaying a pSTAT3 response are most likely active type $B$ cells. Therefore, type $C$ cells are very 

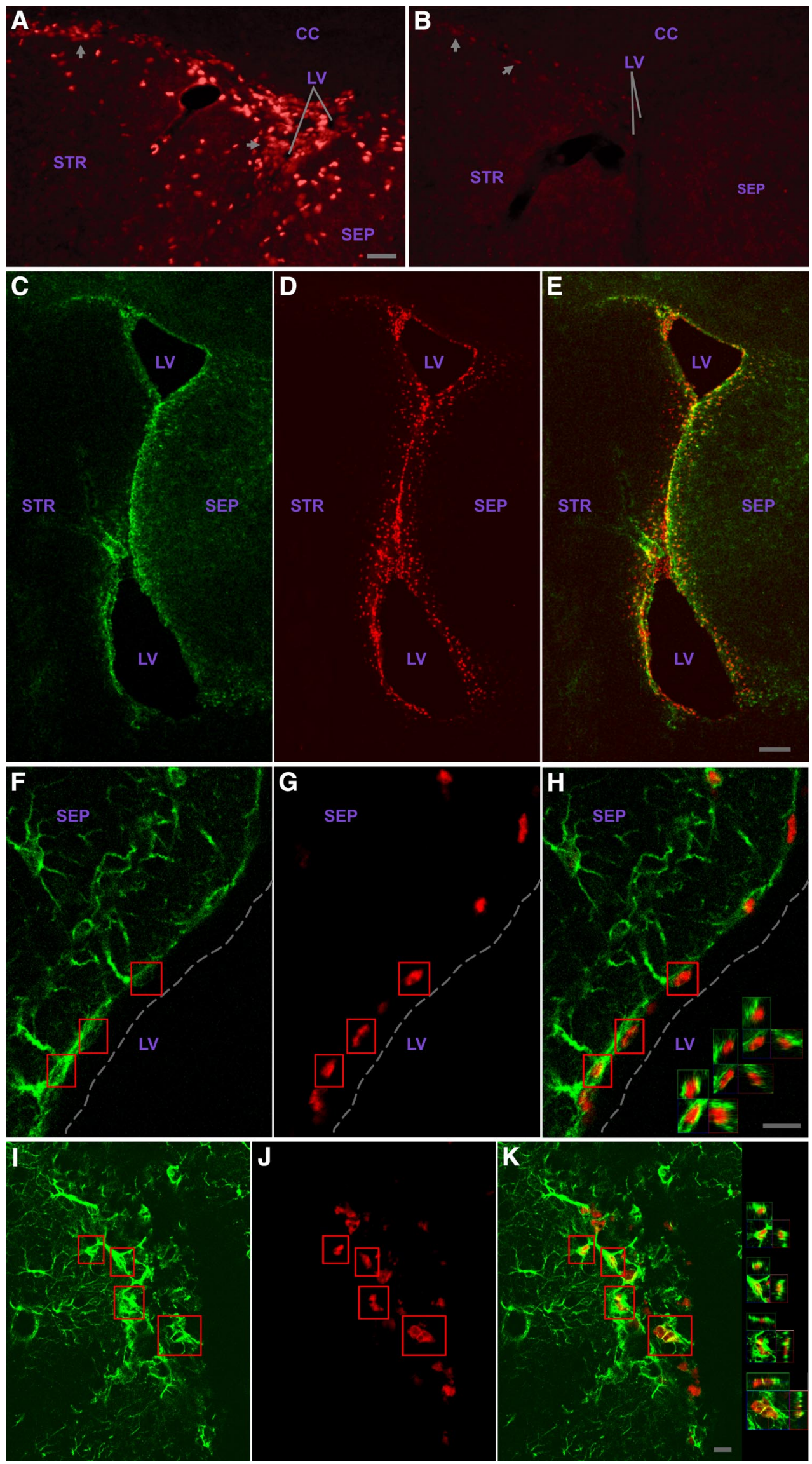

Figure 1. The adult SVZ contains GFAP ${ }^{+}$cells with functional CNTF receptors. As described in the text, pSTAT3 immunohistochemistry of SVZ region injected with CNTF (A) or contralateral side receiving vehicle (B); image flipped horizontally to aid comparison. Images were identically captured and optimized. Arrows indicate examples of SVZ cells. $\boldsymbol{C} \boldsymbol{K}$, Most, and (Figure legend continues.) 

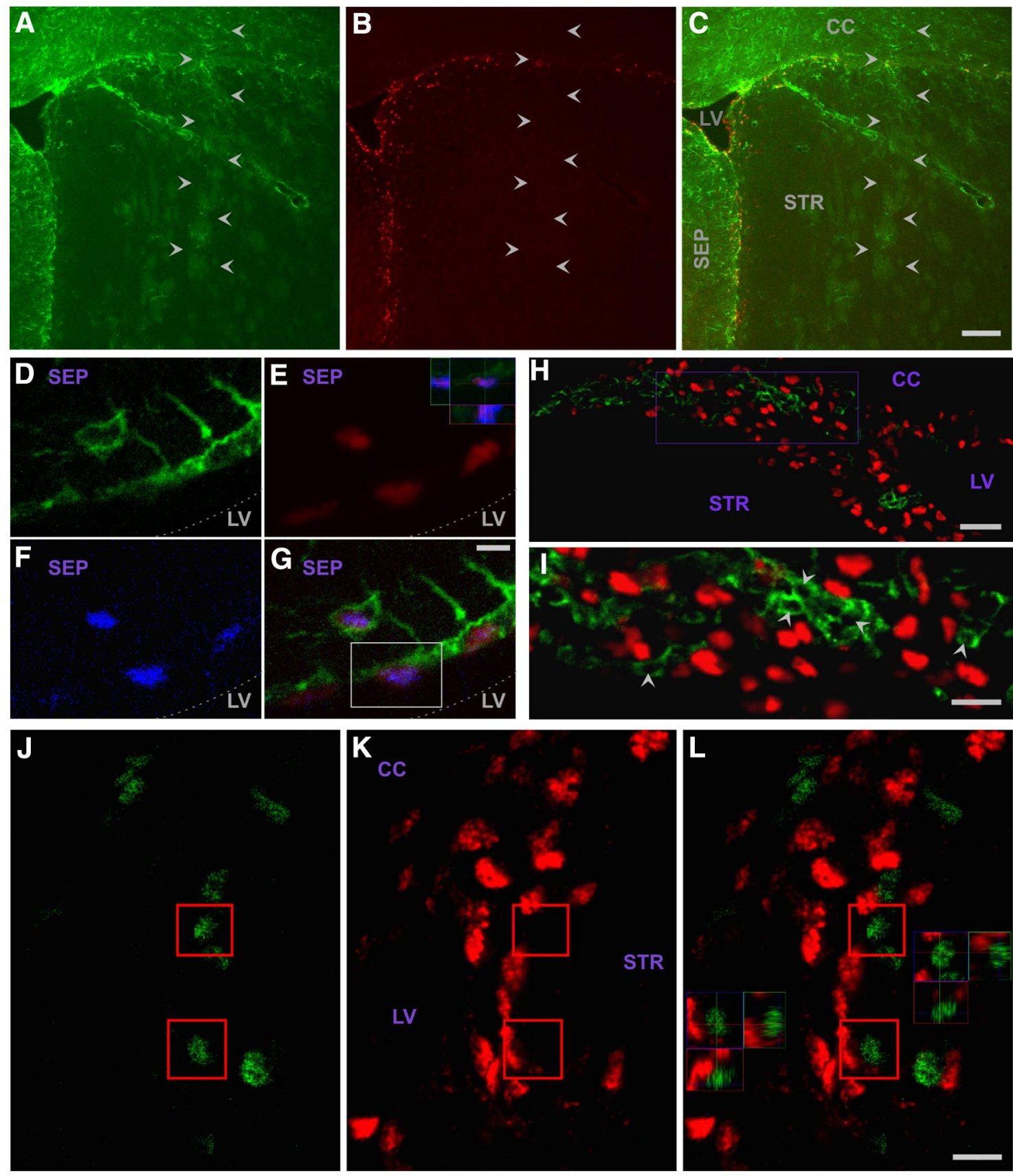

Figure2. Functional in vivo CNTF receptors in the SVZare restricted to type B"stem" cells.A-C,SVZ cells selectively respond to CNTF. Injecting CNTF into striatum away from SVZdemonstrates that SVZGFAP ${ }^{+}$ (green) cells display robust pSTAT3 response (red), whereas other cells, including GFAP ${ }^{+}$cells closer to the needle tract (arrowheads) that receive higher CNTF concentrations, do not respond. D-G, Type B stem cells contain functional CNTF receptors. GFAP ${ }^{+}$(green) SVZ cells with few processes, and retention of BrdU (blue) administered a month before death, display a pSTAT3 response (red) to CNTF. Three individual channels and merged image are presented. $\boldsymbol{B}$, Inset, The 3D views of cell boxed in $\boldsymbol{D}$. Dotted line indicates approximate edge of tissue. $\boldsymbol{H}-\boldsymbol{I}$, PSA-NCAM ${ }^{+}$SVZ cells do not express functional CNTF receptors. PSA-NCAM $^{+}$(green, cytoplasmic label) cells do not display a CNTF-induced pSTAT3 response (red, nuclear). I, Region boxed in $\boldsymbol{H}$ with pSTAT3 signal intensity increased to better demonstrate lack of pSTAT3 label in PSA-NCAM ${ }^{+}$cells "cut" through their nucleus (e.g., arrowheads). J-L, Ascl1 ${ }^{+}$SVZ cells do not express functional CNTF receptors. Ascl1 ${ }^{+}$(green) cells do not display a CNTF-induced pSTAT3 response (red). Two individual channels and merged image in right panel. The 3D views through boxed cells are in $L$. Abbreviations as in Figure 1. Scale bars: $C, 50 \mu \mathrm{m} ; \boldsymbol{E}, 5 \mu \mathrm{m} ; \boldsymbol{H}, 25 \mu \mathrm{m} ; \boldsymbol{I}, 12 \mu \mathrm{m} ; \boldsymbol{L}, 20 \mu \mathrm{m}$.

(Figure legend continued.) likely all, GFAP ${ }^{+}$SVZ cells display a robust pSTAT3 response to CNTF. GFAP signal (green) is cytoplasmic and pSTAT3 signal (red) is nuclear such that comparatively little yellow signal is produced for double-labeled cells. Two individual channels are presented, and merged images are in right panels. $\mathbf{C}-\boldsymbol{E}$, Example showing responsive cells throughout the SVZ. $\boldsymbol{F}-\boldsymbol{H}$, Dorsal septal SVZ with examples of double-labeled cells with few primary processes; 3D views ( $\mathrm{X}, \mathrm{Y}$, and $\mathrm{Z}$ "cuts") through boxed cells are in $\boldsymbol{H}$. Broken line indicates approximate edge of tissue. $\boldsymbol{I}-\boldsymbol{K}$, Examples of RMS double-labeled cells; $3 \mathrm{D}$ views of boxed cells are in $K$. CC, Corpus callosum; STR, striatum; SEP, septum; LV, lateral ventricle. Scale bars: (in $\boldsymbol{A}) \boldsymbol{A}, \boldsymbol{B}, 25 \mu \mathrm{m} ; \boldsymbol{E}, 500 \mu \mathrm{m} ; \boldsymbol{H}, \boldsymbol{K}, 10 \mu \mathrm{m}$. unlikely to be responsive. This conclusion is further supported by the observation that essentially all responsive cells are $\mathrm{GFAP}^{+}$(see above) and type $\mathrm{C}$ cells are GFAP ${ }^{-}$. Ependymal cells also failed to respond to the CNTF challenge (Fig. $1 F-H$ ). In summary, we find that functional CNTF receptors are present in type B stem cells throughout the SVZ but are notably absent from other SVZ cells types, including their type A and C cell progeny.

To further characterize CNTF receptors in the neural stem cell lineage, we performed CNTFR $\alpha$ immunohistochemistry. As with 
the functional CNTF receptors, CNTFR $\alpha$ immunoreactivity was detected in type $\mathrm{B}$ cells but not type A or type $\mathrm{C}$ cells (Fig. $3 A-S$ ).

\section{Cell type-specific localization of endogenous CNTF in the adult SVZ overlapping that of functional CNTF receptors}

Immunohistochemistry, with a well-characterized anti-CNTF antiserum, was used to examine CNTF expression in the adult SVZ. CNTF immunoreactivity was detected in SVZ-type B cells (Fig. 3T, a) but not parenchymal GFAP ${ }^{+}$astrocytes (data not shown). Therefore, both the functional CNTF receptors and a ligand are located in type B cells. However, in contrast to the receptors that are present in essentially all $\mathrm{GFAP}^{+} \mathrm{SVZ}$ cells (e.g., Fig. $1 C-K)$, CNTF expression was detected in a scattered and variable subset of these cells. Most of these $\mathrm{CNTF}^{+}$cells label with acute $\mathrm{BrdU}$ administration, indicating that they are in the proliferative state while expressing both GFAP and CNTF (data not shown), and thus are likely to correspond to so-called activated stem cells (Pastrana et al., 2009). Lower levels of CNTF immunoreactivity were also detected as nonhomogeneous, punctate signal in the ependymal cell layer (Fig. $3 U, W, Y, a$ ). As with the functional CNTF receptors and CNTFR $\alpha$ immunoreactivity, CNTF immunoreactivity was not found in PSA-NCAM ${ }^{+}$ type A cells (Fig. 36 ) or Ascl1 ${ }^{+}$, putative type $\mathrm{C}$ cells (data not shown). Together, these results suggest that CNTF in the adult SVZ may act on type B cells as both a cell-autonomous autocrine/ paracrine signal and a non-cell-autonomous niche signal.

\section{CNTFR $\alpha$ gene disruption in SVZ neural stem/progenitor cells} leads to increased adult neurogenesis

To selectively disrupt all forms of CNTF receptor signaling in SVZ NSP cells, we disrupted the CNTFR $\alpha$ gene, which is required for all forms of endogenous CNTF receptor signaling, regardless of the ligands or signaling pathways involved (Davis et al., 1993; Elson et al., 2000) but is not required for LIF receptor signaling (Ip et al., 1992). Previous work indicates that the unconditional knock-out of CNTFR $\alpha$ leads to universal perinatal death from motor neuron loss (DeChiara et al., 1995), precluding the use of such mice in the study of adult NSP cells. We have previously characterized (Lee et al., 2008) a mouse line with exons 3-5 of the CNTFR $\alpha$ gene flanked by loxP sites ("floxed") such that Creinduced excision creates a null mutation, based on both the unconditional CNTFR $\alpha$ knock-out data (DeChiara et al., 1995) and known structure-function relationships for related cytokine receptors (Bazan, 1990). As previously described (Lee et al., 2008), homozygous floxed mice (i.e., flxCNTFR $\alpha^{+/+}$) are born at predicted Mendelian frequency and survive with no apparent abnormalities or decreases in CNTFR $\alpha$ expression or CNTF receptor function. Crossing the floxed mice with a "deleter" line that produces floxed gene excision in all cells results in the expected perinatal death with motor neuron loss in all homozygous floxed mice (Lee et al., 2008), as previously seen with universal CNTFR $\alpha$ gene disruption (DeChiara et al., 1995), indicating that Cre excision of the floxed gene functionally inactivates it.

To disrupt the CNTFR $\alpha$ gene in SVZ NSP cells and not motor neurons, we crossed the flxCNTFR $\alpha^{+/+}$mice with hGFAP-Cre mice in which Cre expression is driven by elements of the human GFAP promoter (Zhou et al., 2001). The GFAP promoter would be expected to drive Cre expression and floxed gene excision in $\mathrm{GFAP}^{+}$cells including GFAP ${ }^{+}$type B stem cells of the SVZ (Doetsch et al., 1999; Laywell et al., 2000; Imura et al., 2003; Morshead et al., 2003; Garcia et al., 2004). The floxed genes should also be excised in all progeny of the affected type B cells. A previous initial analysis is consistent with these predictions
(Zhou et al., 2001) and also found that some oligodendrocytes and a subset of telencephalic neurons are affected, suggesting that Cre expression begins in some embryonic NSP cells. Other work with the same mouse line identifies these cells as mid-embryonic radial glia (Malatesta et al., 2003), precursors to the adult NSP cells (Merkle et al., 2004). Importantly, the argument here for CNTF receptor signaling regulating NSP cells is not based on a claim of absolute adult NSP cell specificity for the hGFAP-Cre construct. Instead, it involves the consistent results obtained with both the hGFAP-Cre and AAV-Cre methods (see below), further supported by the restricted expression of functional CNTF receptors in type B cells. Thus, the adult-type B cells are essentially the only cells affected by both hGFAP-Cre and the SVZ AAV-Cre injections, which also express functional CNTF receptors, a requirement given that otherwise receptor disruption would not produce an effect.

We crossed hGFAP-Cre mice with reporter mice in which Cre-directed gene excision leads to expression of EGFP (CAGCAT-EGFP; Nakamura et al., 2006) or $\beta$-galactosidase ( $\beta$ gal) (ROSA26) (Soriano, 1999). Analysis of mice from 2 to 7 months of age reliably revealed the expected reporter signal throughout the SVZ (Fig. 4A, $B$ ) and many cells of the olfactory bulb granule and glomerular layers, consistent with neurons derived from excised SVZ type B cells (Fig. 4C). In contrast, motor neurons were reporter negative (Fig. $4 D$ ). No signal was seen in mice not carrying reporter genes. Multilabeling identified reporter signal in $\mathrm{GFAP}^{+}$SVZ cells, some of which were proliferative and contained few primary processes (Fig. $4 E-L$ ) (characteristics of type B stem cells). In addition, CAG-CAT-EGFP reporter signal was detected in essentially all RMS neuroblasts (Fig. $4 M-O$ ) and olfactory bulb PG and GL neurons (Fig. 4P-S; and data not shown). The CAG-CAT-EGFP reporter was particularly effective at detecting excision of floxed sequence in the PG and GL neurons, in that, in comparison, only approximately half of these cells were ROSA26 reporter-positive, in agreement with previous work (Malatesta et al., 2003).

Breeding flxCNTFR $\alpha^{+/-} /$hGFAP-Cre $^{+/-}$mice with flxCNTFR $\alpha^{+/-} /$hGFAP-Cre $^{-1-}$ mice leads to flxCNTFR $\alpha^{+/+} /$ hGFAP-Cre ${ }^{+-}$"knock-out" mice at the expected Mendelian frequency. These mice show no increase in mortality throughout postnatal development and adulthood, nor did we detect any abnormalities in gross brain morphology (or any other gross morphology).

We next used the SVZ CNTF injection-pSTAT3 assay to confirm that the targeted SVZ CNTF receptors are depleted and functionally disrupted. We injected 2- to 3-month-old knockout mice and flxCNTFR $\alpha^{-1-} /$ hGFAP-Cre $^{+/-}$age-matched littermate controls with CNTF. In contrast to the control SVZs, which displayed the normal intense PSTAT3 responses throughout the SVZ, knock-out SVZs revealed very little evidence of functional CNTF receptors (Fig. 5), indicating that the hGFAPCre leads to a near-complete disruption of CNTF receptors throughout the SVZ. With rare exceptions, the SVZ cells of the knock-outs did not contain the intense CNTF-induced pSTAT3 signal seen in controls but instead were comparable to that seen in naive and vehicle-injected controls. The few responding cells in the knock-out mice are likely examples of rare, incomplete CNTFR $\alpha$ gene excision. To further confirm that the targeting of CNTFR $\alpha$ was effective, we used CNTFR $\alpha$ immunohistochemistry and found a near-complete depletion of CNTFR $\alpha$ immunoreactivity in knock-out SVZs, relative to the control SVZs (Fig. $6 A-H)$.

To determine the effect of the CNTF receptor disruption on the overall neurogenic activity of the NSP cells, we compared the 

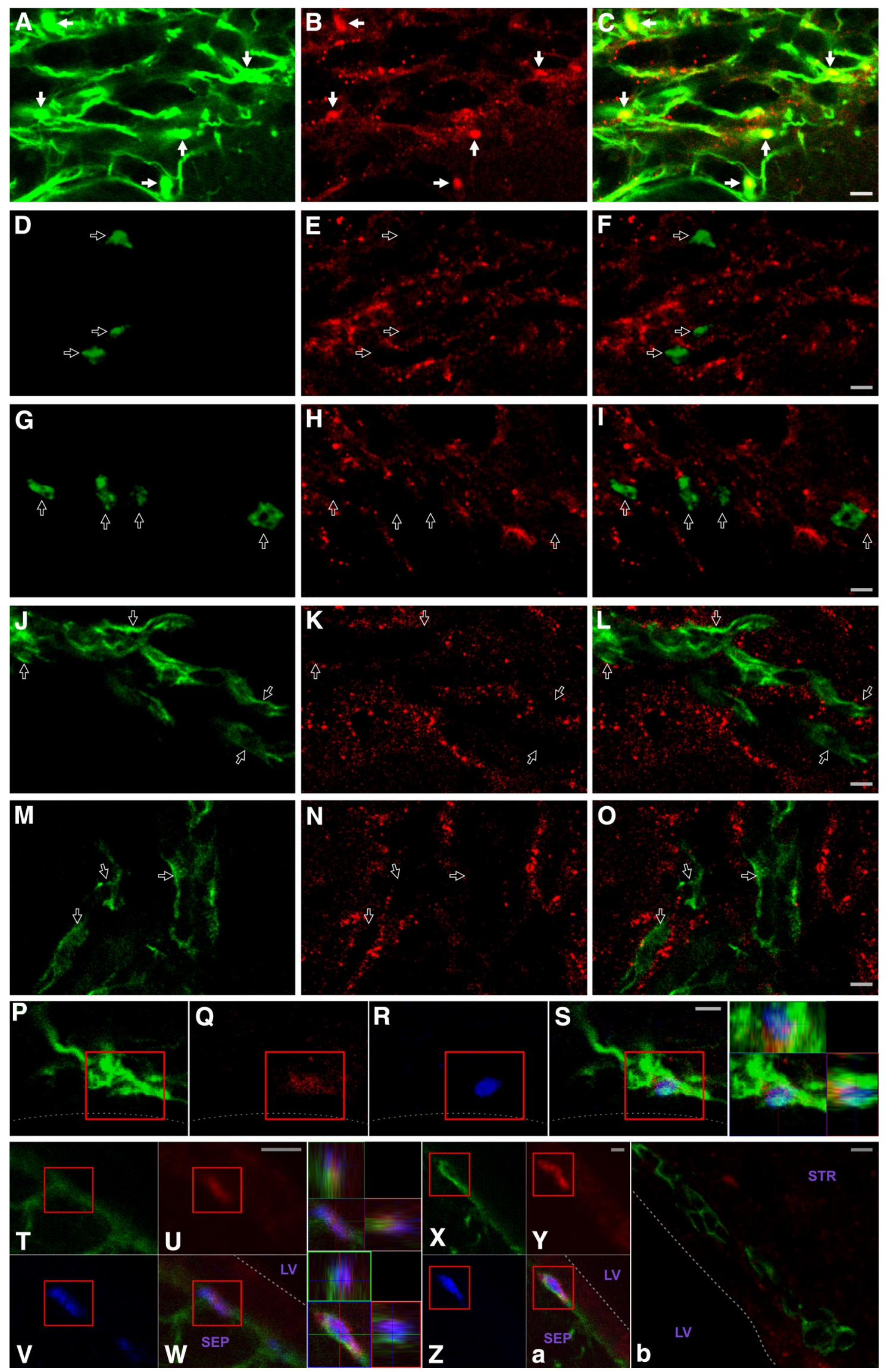

Figure 3. CNTFR $\alpha$ and CNTF are expressed in type B stem cells. Although the CNTFR $\alpha$ immunohistochemistry signal is not as "clean" as the pSTAT3 signal (e,g,. Fig. 2), both approaches reveal the same cell type-specific pattern of expression for CNTF receptors. A-C, CNTFR $\alpha$ immunoreactivity (red) colocalizes with GFAP (green) in the dorsal later SVZ. Solid (Figure legend continues.) 
neuroblast populations of adult (4-7 months old) control and knock-out mice by quantifying the density of PSA-NCAM ${ }^{+}$cells in the RMS, the pathway taken by SVZ-derived neuroblasts on their way to the olfactory bulb. The knock-outs displayed an increase in the number of neuroblasts in that the number of neuroblasts in the knock-outs was $192.7 \pm 6.3 \%$ of control values ( $p<0.015 ; t=4.56 ; 5$ age-matched pairs).

To quantify proliferating SVZ cells, BrdU-labeled cells were counted in knock-out and control mice after acute BrdU administration (five, $120 \mathrm{mg} / \mathrm{kg}$ injections at $2 \mathrm{~h}$ intervals, last injection at $0.5 \mathrm{~h}$ before perfusion). The knock-outs displayed a significant increase in total $\mathrm{BrdU}^{+}$SVZ cells with $119.7 \pm 7.3 \%$ relative to controls ( $p<0.05 ; t=2.68$; 6 age-matched pairs; $2-7$ months). Acute BrdU administration primarily labels the rapidly dividing type $\mathrm{C}$ cells, and to some extent, type A cells. Therefore, this result is also consistent with increased neurogenic activity in the knockout mice.

We next quantified $\mathrm{BrdU}^{+} \mathrm{NeuN}^{+}$neurons in the olfactory bulbs of mice perfused a month after BrdU injection $(150 \mathrm{mg} / \mathrm{kg}$ twice/d for $2 \mathrm{~d}$ ). As expected, confocal 3D reconstruction of randomly selected $\mathrm{BrdU}^{+} \mathrm{PG}$ and GL cells indicated that they were essentially all NeuN ${ }^{+}$in both knock-outs and controls (e.g., Fig. $6 I-O)$. In mice injected at 6 months of age and perfused at 7 months, the knock-outs displayed an increase in $\mathrm{BrdU}^{+} \mathrm{PG}$ neurons $(147.3 \pm 11.5 \%$ relative to the controls; $p<0.03 ; t=4.11 ; 4$ pairs), again consistent with a knock-out-induced increase in neurogenic activity. Moreover, this result suggests that the increase in neurogenic activity in the SVZ leads to an increase in the generation of new mature olfactory bulb neurons (neurogenesis). A similar result was observed in mice injected at 2 months and perfused at 3 months $(150.1 \pm 12.2 \%$ in knock-outs relative to controls; $p<0.02 ; t=4.67 ; 4$ pairs; Fig. $6 P, Q$ ). The knock-outs also displayed more BrdU-labeled GL neurons than controls at each time point but with more variability such that neither time point by itself reached statistical significance (2-3 months; $157.3 \pm 35.2 \%$ in knock-outs relative to controls; $p>0.05 ; t=$ 3.11; 4 pairs; $6-7$ months; $145.1 \pm 40.2 \%$ in knock-outs relative to controls; $p>0.05 ; t=0.50 ; 5$ pairs). However, combining the GL data from the two time points ( $2-3$ and $6-7$ months) revealed a significant overall effect $(p<0.05 ; F=6.38)$, indicating that the knock-out mice contained significantly more BrdU-labeled GL neurons than controls. Therefore, the CNTFR $\alpha$ knock-outinduced increase in neurogenic activity leads to an increase in the generation of both PG and GL neurons.

\footnotetext{
$\leftarrow$

(Figure legend continued.) arrows indicate regions of intense label for both. D-I, CNTFR $\alpha$ immunoreactivity (red) does not colocalize with $\mathrm{Ascl}^{+}{ }^{+}$(green) cells (presumptive type C cells) in the dorsal later SVZ. Open arrows indicate examples of Ascl $1^{+}$cells. J-0, CNTFR $\alpha$ immunoreactivity (red) does not colocalize with PSA-NCAM ${ }^{+}$(green) cells in the dorsal later SVZ. Open arrows indicate examples of PSA-NCAM ${ }^{+}$cells. The dorsal lateral SVZ was chosen for these illustrations because it contains many well-labeled GFAP ${ }^{+}, \mathrm{PSA}^{-\mathrm{NCAM}^{+}}{ }^{+}$, and $\mathrm{AsCl}^{+}{ }^{+}$cells. P-S, Example of a GFAP ${ }^{+}$(green)/CNTFR $\alpha^{+}$(red)/ BrdU retaining (blue) cell in the striatal SVZ with few primary processes. Line indicates approximate edge of the tissue. Far left panel, 3D view. $\mathbf{T}-\mathbf{Z}, \boldsymbol{a}$, CNTF (red) is found in GFAP ${ }^{+}$(green) SVZ cells with few primary processes that also label for BrdU (blue) administered a month before perfusion. 3D views of boxed triplelabeled cells are presented. Lower levels of CNTF are also detected as label in the ependymal cell layer. $\boldsymbol{b}$, In contrast, no CNTF is detected in PSA-NCAM ${ }^{+}$(green) SVZ cells. Dotted lines indicate the approximate ventricular edge of tissue. Abbreviations as in Figure 1. Scale bars, $5 \mu \mathrm{m}$.
}

CNTFR $\alpha$ gene disruption in the SVZ neural stem/progenitor cells differentially affects adult olfactory bulb interneuron subpopulations

We next asked whether the greater number of new neurons produced in the knock-outs had a measurable effect on the total populations of PG neurons. We quantified calbindin $(\mathrm{CB})^{+}$, calretinin $(\mathrm{CR})^{+}$, and tyrosine hydroxylase $(\mathrm{TH})^{+}$neurons in the PG of 7-month-old knock-outs and controls, as markers that identify three separate populations of PG neurons. The knockout mice displayed an increase in $\mathrm{CB}^{+}$neurons $(134.1 \pm 5.2 \%$ relative to controls, $p<0.03 ; t=3.28 ; 5$ pairs), an increase in $\mathrm{CR}^{+}$neurons $(147.1 \pm 17.8 \%$ of controls; $p<0.03 ; t=3.96 ; 4$ pairs), but no change (104.6 $\pm 10.3 \%$ of controls) in $\mathrm{TH}^{+}$neurons $(p>0.5 ; t=0.65 ; 5$ pairs). We did not detect any change in the overall size of the olfactory bulb in the knock-outs (94.6 \pm $7.6 \%$ of controls; $p>0.05 ; t=0.61 ; 3$ pairs). Therefore, the data suggest an increase in the density of $\mathrm{CB}^{+}$and $\mathrm{CR}^{+}$neurons.

The differential changes in PG neuron subtypes raises the interesting possibility that CNTF receptor signaling in type B cells selectively inhibits their differentiation along $\mathrm{CB}$ and $\mathrm{CR}$ lineages while having little to no effect on their differentiation along the $\mathrm{TH}$ lineage. Given that the CNTF receptors are disrupted throughout the SVZ as indicated by both the pSTAT3 assay of functional CNTF receptors (Fig. 5) and CNTFR $\alpha$ immunohistochemistry (Fig. 6A-H), it is unlikely that the differential effect of receptor disruption on PG neuron cell types results from hGFAPCre failing to affect type B cells destined to generate TH cells. We also performed reporter/TH multilabeling and found, as expected, reporter ${ }^{+} / \mathrm{TH}^{+}$PG neurons (Fig. $6 R-T$ ), further confirming that the lack of a TH effect in the knock-outs is not the result of hGFAP-Cre failing to affect the NSP cells involved in generating TH neurons.

We next examined PG populations of young adult (2 month) knock-out and control mice to determine whether the changes in the density of $\mathrm{CB}$ and $\mathrm{CR}$ populations in the olfactory bulb develop during adulthood or are present by young adulthood. We found that the $\mathrm{CB}, \mathrm{CR}$, and $\mathrm{TH}$ populations are not significantly affected in the knock-outs by 2 months of age (CB: $95.9 \pm 9.9 \%$ of controls $[p>0.5 ; t=0.54 ; 4$ pairs], CR: $93.3 \pm 3.2 \%$ of controls $[p>0.15 ; t=1.90 ; 4$ pairs] , TH: $104.7 \pm 12.1 \%$ of controls $[p>0.5 ; t=0.27 ; 4$ pairs $]$ ), suggesting that the knockout-induced increases are produced between 2 and 7 months of age, likely by a gradual accumulation of adult-born neurons. We have also confirmed the findings of others (Bagley et al., 2007; Ninkovic et al., 2007) that TH PG neurons continue to be generated between 2 and 7 months of age (data not shown). Therefore, it is doubtful that the differential effect of CNTF receptor disruption on PG cell populations simply reflects a lack of TH cell generation during this period. It is also unlikely that NSP cells that are part of the TH lineage do not express functional CNTF receptors because we find with our pSTAT3 assay that essentially all $\mathrm{GFAP}^{+}$SVZ cells throughout the SVZ respond to CNTF (Figs. $1 C-K, 2 A-G$, and 5), including regions previously shown to contain many NSP cells in the TH lineage (Merkle et al., 2007).

We also used active caspase 3 immunohistochemistry to determine whether the receptor disruption had any detectable effect on apoptotic cell death in the SVZ. Knock-outs and controls (2-7 months) both displayed a small number of caspase $3^{+}$cells with no knock-out versus control difference (knock-out $=106.5 \pm$ $15.7 \%$ of controls; $p>0.5 ; t=0.41 ; 5$ age-matched pairs). The olfactory bulb and RMS contained very few caspase $3^{+}$cells, with no indication of a knock-out versus control difference. Therefore, although it is not possible to completely rule out any cell 

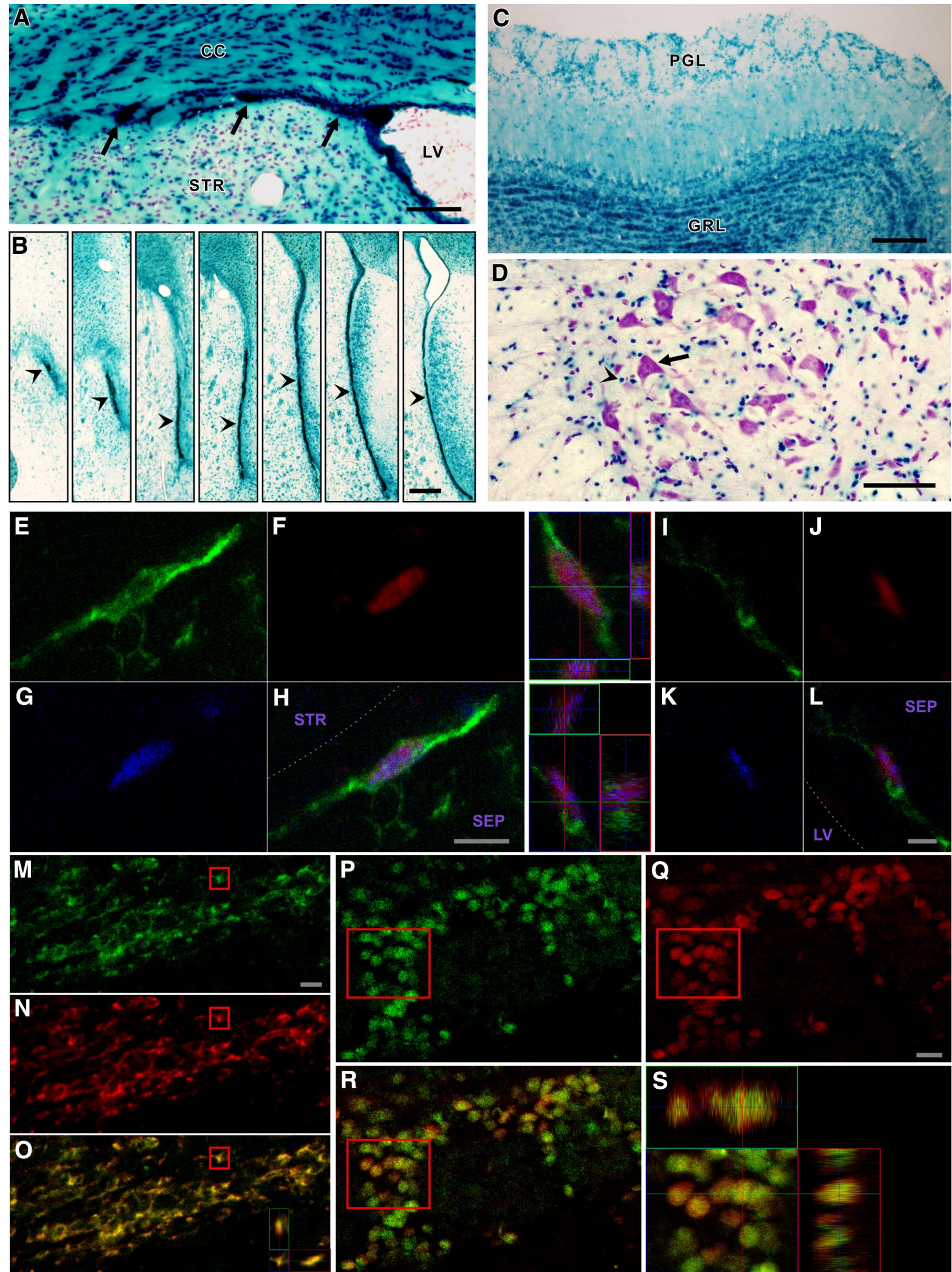

Figure 4. hGFAP-Cre induces floxed gene excision in type B stem cells and their progeny. $A-D$, Xgal histology of hGFAP-Cre ${ }^{+} /$ROSA2 ${ }^{+}$mice. (A) hGFAP-Cre gene excision in SVZ, including regions extending beneath white matter (arrows). $\boldsymbol{B}$, hGFAP-Cre gene excision throughout SVZ and RMS (arrowheads in rostral to caudal series of sections). Medial is to the right in all panels. $\boldsymbol{C}$, hGFAP-Cre gene excision in olfactory bulb granule layer (GRL) and periglomerular layer (PGL) cells. D, Spinal cord motor neurons (e.g., arrow) are not affected, in contrast to (Figure legend continues.) 
death involvement in the knock-out versus control differences we observe in other indexes, it unlikely makes a significant contribution. Moreover, if disrupting the CNTF receptor were to have an effect on NSP cell survival, one would expect the effect to be an increase in cell death leading to an apparent decrease in neurogenesis (i.e., opposite of what we observe) given that the literature indicates that administration of exogenous CNTF can promote cell survival (e.g., Clatterbuck et al., 1993; Dale et al., 1995).

\section{Adult-onset CNTFR $\alpha$ gene disruption in SVZ neural stem/ progenitor cells also leads to increased adult neurogenesis} Although the data presented above, particularly the adultinitiated changes in PG populations, suggest that the CNTF receptor regulates adult neurogenesis, it is still theoretically possible that disrupting the receptor with hGFAP-Cre during development produces permanent defects in the NSP cell system, causing the system to function abnormally in the adult, independent of any adult CNTF receptor signaling. Therefore, we disrupted adult SVZ NSP cell CNTF receptors by injecting adult floxed and control mice adjacent to the lateral ventricle (see Materials and Methods) with an AAV-2-type recombinant adenoassociated virus that drives Cre expression (AAV-Cre) (described by Lee et al., 2008).

We selected the AAV-Cre vector over retrovirus vectors because retroviruses preferentially infect rapidly dividing cells and therefore are effective at labeling and manipulating type $\mathrm{C}$ cells and type A cells (e.g., Doetsch et al., 2002; Hack et al., 2005) but infect very few of the slowing dividing type B cells (Hack et al., 2005). Both the pSTAT3 assay of functional CNTF receptors (Fig. 2) and CNTFR $\alpha$ immunohistochemistry (Fig. 3A-S) indicate that CNTF receptors are present in type B cells but absent from type $\mathrm{C}$ and type A cells. Therefore, to disrupt CNTF receptors, a method was needed to infect type B cells so that the Cre could excise the floxed CNTFR $\alpha$ gene in cells expressing the receptor. $\mathrm{AAV}$ infection is not dependent on cell proliferation, and our multilabeling experiments indicate that the AAV-Cre vector indeed infects type B cells of the adult SVZ (see Fig. $7 B-N$ ). Moreover, we chose the AAV-Cre vector because our previous experience using it to disrupt the same floxed CNTFR $\alpha$ construct in another cell type (motor neurons) indicated that it produced sufficient Cre to excise this particular floxed CNTFR $\alpha$ gene and deplete CNTFR $\alpha$ (Lee et al., 2008).

After initial pilot studies, AAV-Cre was injected into the SVZ (see Materials and Methods) of 4- to 5-month-old, ROSA26 reporter-positive flxCNTFR $\alpha^{+/+}$"knock-out" and age-matched flxCNTFR $\alpha^{-l-}$ control mice that were perfused 6 months later. Cre-induced excision was detected in large populations of SVZ cells, as well as other smaller populations of cells (e.g., Fig. 7A). No signal was seen in vehicle-injected or reporter-negative mice. Whereas AAV-2 type vectors display a strong preference for neu-

\footnotetext{
(Figure legend continued.) small non-neuronal cells (presumptive astrocytes; e.g., arrowhead). $\boldsymbol{A}, \boldsymbol{D}$, Sections were $\mathrm{CV}$ counterstained. $\boldsymbol{E}-\boldsymbol{L}$, Proliferating (BrdU ${ }^{+}$; blue) SVZ, GFAP ${ }^{+}$ (green) cells with few primary processes (type $B$ stem cells) displaying $\beta$ Gal reporter signal (red) in hGFAP-Cre mice. Top 3D view in middle panels, cell in $\boldsymbol{E}-\boldsymbol{H}$; bottom 3D view, cell in $\boldsymbol{I} \boldsymbol{L}$. Septal type $B$ cell examples are shown because type $B$ cell morphology is clearest in this region. Dotted line indicates approximate edge of tissue. $\mathbf{M - 0}$, hGFAP-Cre gene excision in essentially all RMS neuroblasts. CAG-CAT-EGFP reporter-positive (green), doublecortin ${ }^{+}$(red) RMS neuroblasts with merged view in $\mathbf{0}$. 3D view in $\mathbf{0}$, boxed cell. $\mathbf{P}$ - $\mathbf{S}$, hGFAP-Cre gene excision in essentially all PG neurons. CAG-CAT-EGFP reporter (green), $\mathrm{NeuN}^{+}$(red), and merged views. 3D view in $S$, boxed cells. Abbreviations as in Figure 1. Scale bars: $A, 50 \mu \mathrm{m} ; \boldsymbol{B}, 200 \mu \mathrm{m} ; \boldsymbol{C}, 100$ $\mu \mathrm{m} ; \boldsymbol{D}, 50 \mu \mathrm{m} ; \boldsymbol{H}, 5 \mu \mathrm{m} ; \boldsymbol{L}, 2 \mu \mathrm{m} ; \boldsymbol{M}, 10 \mu \mathrm{m} ; \mathbf{Q}, 10 \mu \mathrm{m}$.
}

ronal infection when injected into other brain regions (Bartlett et al., 1998; Burger et al., 2004), the SVZ cell infection is consistent with reports that AAV-2 vectors efficiently infect human NSP cells in culture (Wu et al., 2002) and rat SVZ NSP cells in vivo (Henry et al., 2007). Examination of the olfactory bulbs of the same SVZ-injected mice revealed reporter-positive cells in the granule cell layer and glomerular layer of the olfactory bulb (e.g., Fig. $7 W, X)$, consistent with AAV-Cre infection of SVZ NSP cells followed by migration and differentiation of affected NSP cell progeny. We identified both Cre (Fig. $7 B-D$ ) and reporter (Fig. $7 E, F)$ signals in $\mathrm{GFAP}^{+} \mathrm{SVZ}$ cells with few primary processes. In addition, triple labeling experiments revealed reporter signals in $\mathrm{GFAP}^{+}$SVZ cells with few primary processes that also retain BrdU injected a month before death (Fig. $7 G-N$ ). Therefore, the AAV-Cre infects type B cells leading to floxed gene excision in this population. We also confirmed that the AAV-Cre injection leads to the designed knock-out-mouse-specific reduction or elimination of CNTFR $\alpha$ immunoreactivity in infected SVZ regions (Fig. 7O, $P$ )

Finally, we quantified reporter-positive $\left(\mathrm{Xgal}^{+}\right)$cells in the olfactory bulb (e.g., Fig. $7 W, X$ ). The knock-out mice displayed more reporter-positive PG cells than controls $(147.0 \pm 16.5 \%$ of controls; $p<0.05 ; t=2.85 ; 5$ pairs) and similarly more reporterpositive GL cells than controls $(146.8 \pm 14.5 \%$ of controls; $p<$ $0.05 ; t=3.23$; 4 pairs). The $3 \mathrm{D}$ confocal reconstruction of randomly selected reporter-positive PG and GL cells confirmed that these cells are essentially all $\mathrm{NeuN}^{+}$in both knock-outs and controls, as anticipated (e.g., Fig. 7Q-V). Thus, the AAV-Cre data are consistent with the hGFAP-Cre data described above, in that they both indicate that disruption of CNTF receptors leads to a $\sim 50 \%$ increase in adult neurogenesis for both PG and GL neurons. Moreover, the AAV-Cre data indicate that adult CNTF receptor signaling regulates neurogenesis in adulthood independent of any roles $\mathrm{CNTF}$ receptor signaling may play during development.

\section{CNTF receptors and adult-type $B$ stem cell maintenance}

Because type B stem cells are the NSP cells with CNTF receptors, the above data suggest that in vivo disruption of CNTF receptors in these cells leads to increased neurogenesis, further suggesting that the receptor signaling plays an essential role in inhibiting neurogenesis. Some in vitro data suggest that CNTF receptor signaling promotes the self-renewal of SVZ stem cells at the expense of neuronal differentiation (Shimazaki et al., 2001; Muller et al., 2009). If this also occurs in vivo, the increased neurogenesis we observe after receptor depletion may result from lost CNTF receptor signaling that normally directs type B stem cells to selfrenew rather than differentiate. If so, then disruption of CNTF receptor signaling could lead to a depletion of these cells over time because of insufficient replacement through self renewal.

Therefore, we examined knock-out and control mice to determine whether in vivo CNTFR $\alpha$ depletion in type B cells leads to a decrease in this cell type over time. We looked at 7-month-old mice because the above data indicate that the receptor depletion leads to an increase in neurogenesis, and potentially decreased self-renewal, during the 5 months leading up to this time point. Knock-out and control mice were injected with $\operatorname{BrdU}$ at 6 months of age and perfused for analysis at 7 months to identify long term resident, proliferative SVZ cells $\left(\mathrm{BrdU}^{+}\right)$that are also $\mathrm{GFAP}^{+}$with few primary processes. In vivo targeted cell ablation and fate mapping studies indicate that these are the defining characteristics of the type B stem cells responsible for in vivo SVZ derived neurogenesis (Garcia et al., 2004). 

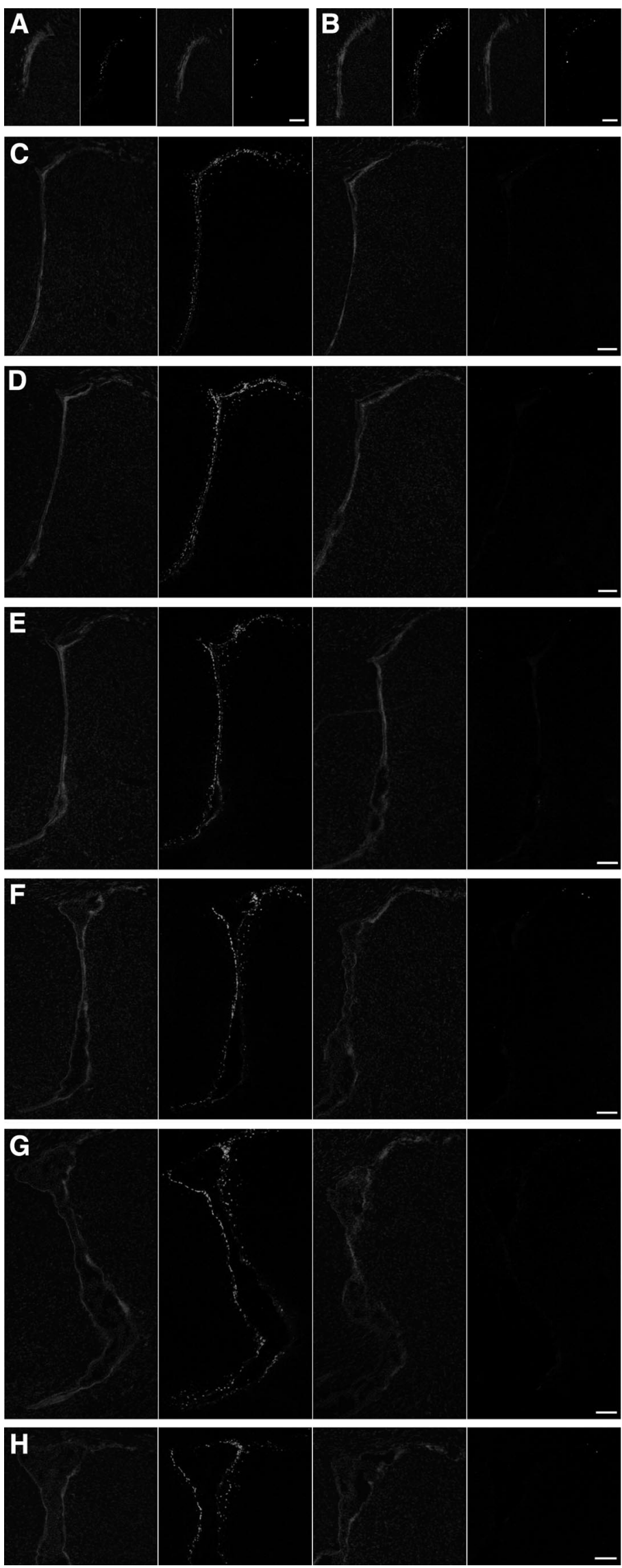

Figure 5. hGFAP-Cre-induced excision of the floxed CNTFR $\alpha$ gene disrupts functional CNTF receptors. The CNTF-induced SVZ pSTAT3 response of control mice is greatly reduced in hGFAP-Cre, floxed CNTFR $\alpha$ "knock-out" mice with only rare cells displaying
In both knock-out and control mice at 7 months of age, many of the $\mathrm{BrdU}^{+} /$ $\mathrm{GFAP}^{+}$labeled cells were found in the dorsal aspect of the septal SVZ. Moreover, almost all of these displayed few primary processes (e.g., Fig. 8). Accurate quantification of the cells is feasible because $\mathrm{GFAP}^{+}$cells of this region are less densely packed and more intensely labeled than in other SVZ regions, and their type B cell morphology of few primary processes is much more easily identified (Fig. 8).

Quantification of these cells in the 7-month-old knock-out and control mice indicated that disruption of CNTF receptor signaling has no effect on the size of this population, with the knock-out mice displaying $102.5 \pm 15.8 \%$ as many type B cells as controls $(p>0.5 ; t=0.16 ; 6$ pairs $)$. Therefore, if CNTF receptor signaling is essential for the self-renewal of these cells in vivo, other compensatory mechanisms must be involved in maintaining this population.

Although we examined type B cells in the dorsal septal SVZ because they can be accurately quantified in this region, the literature indicates that much of adult neurogenesis derives from the lateral/striatal SVZ, including the dorsal lateral extension/corner and the dorsal and ventral aspects of the lateral/ striatal SVZ (e.g., Merkle et al., 2007; Brill et al., 2008; Ihrie et al., 2011). Unfortunately, the generally weaker GFAP soma label in these regions, as well as the unorganized nature in which the $\mathrm{GFAP}^{+}$cells intertwine processes, does not allow for consistent assignment of the nuclear BrdU label to individual $\mathrm{GFAP}^{+}$cells. This precludes accurate quantitative analysis of BrdU-retaining/ $\mathrm{GFAP}^{+}$cells in these regions. That said, inspection of these regions in mice administered BrdU a month before death and processed for GFAP/BrdU immunohistochemistry suggests that most of the BrdUretaining cells are likely $\mathrm{GFAP}^{+}$.

Therefore, we counted the BrdUretaining cells in the lateral SVZ regions of those same animals used for the dorsal septal SVZ analysis. We found that the knockout mice displayed a significant increase in the number of the labeled cells (175.0 \pm $27.5 \%$ of controls; $p<0.01$; Fig. 9).

pSTAT3 elevation comparable to controls. Each set of four images presents, from left to right: DAPI stain of control section, pSTAT3 immunohistochemistry of same control section, DAPI stain of knock-out section, and PSTAT3 immunohistochemistry of same knock-out section. $\boldsymbol{A}-\boldsymbol{H}$, The sets of images are ordered rostral to caudal through the SVZ. Medial is to the left in all cases. The knock-out mouse and its littermate control pair were processed in parallel. All compared images were identically captured and optimized. Scale bars, $100 \mu \mathrm{m}$. 


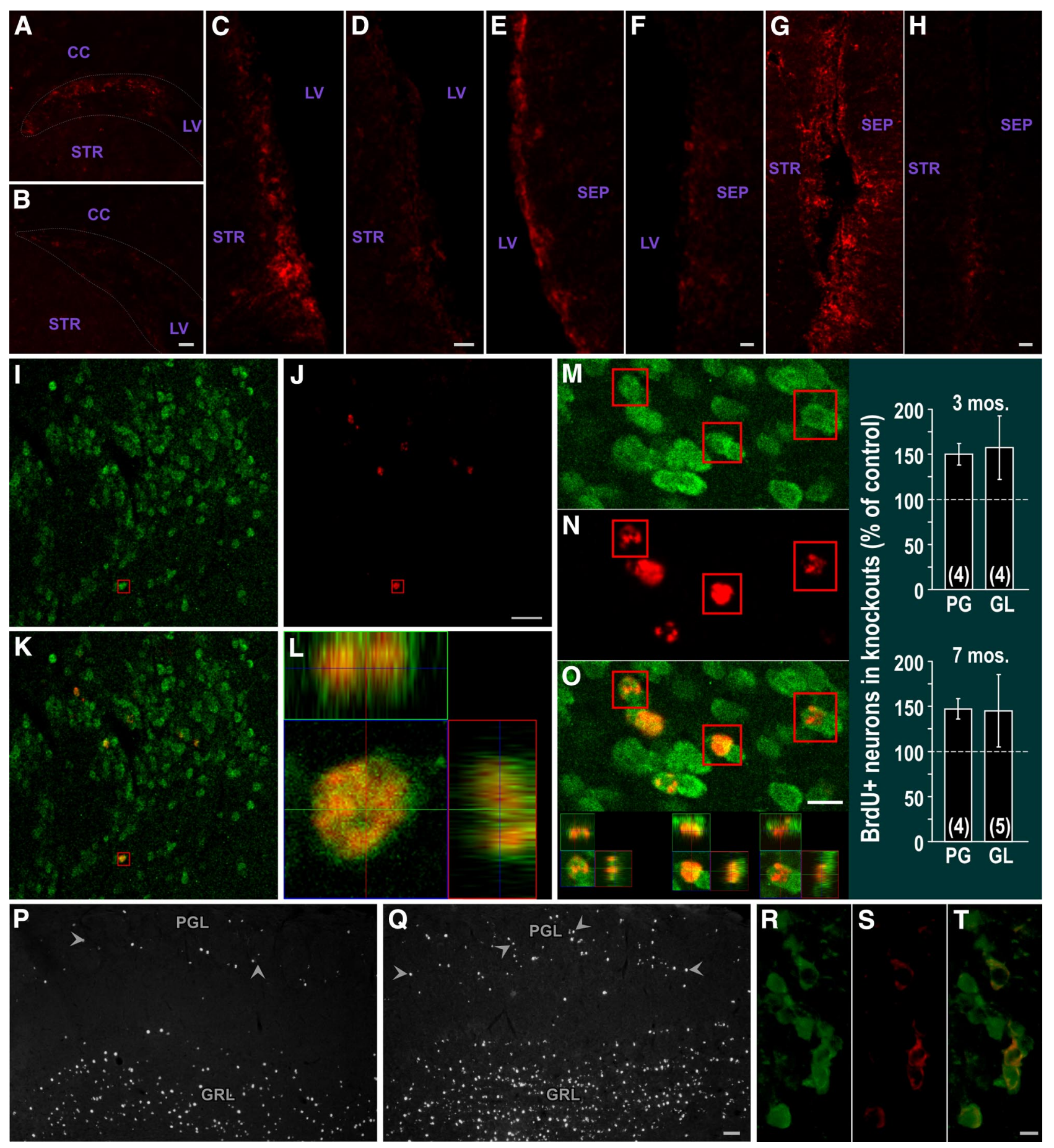

Figure 6. Depletion of SVZCNTFR $\alpha$ and increased olfactory bulb neurogenesis in hGFAP-Cre, floxed CNTFR $\alpha$ "knock-out" mice. CNTFR $\alpha$ immunohistochemistry of control ( $A, C, E, G)$ or knock-out $(\boldsymbol{B}, \boldsymbol{D}, \boldsymbol{F}, \boldsymbol{H})$ SVZ. $\boldsymbol{A}, \boldsymbol{B}$, Dorsal lateral SVZ. $\boldsymbol{C}, \boldsymbol{D}$, Lateral/striatal SVZ. $\boldsymbol{E}, \boldsymbol{F}$, Medial/septal SVZ. $\boldsymbol{G}, \boldsymbol{H}$, Ventral SVZ. Each set of compared images was acquired and optimized identically. The knock-out mouse and its littermate control pair were processed in parallel. Dotted lines outline approximate borders of dorsal lateral SVZ. I-O, Multilabel, 3D confocal data from mice administered BrdU 1 month before death indicate that essentially all BrdU-labeled cells in the granular layer (GRL) and PG layer (PGL) of the olfactory bulb are NeuN ${ }^{+}$neurons. Examples of neurons (NeuN ${ }^{+}$; green) labeled with BrdU (red). I-L, PG neurons. M-0, GL neurons. Boxed cells shown as 3D view. P, Q, hGFAP-Cre, floxed CNTFR $\alpha$ "knock-out" mice display an increase in BrdU-labeled cells in the granular layer (GRL) and PG layer (PGL) of the olfactory bulb 1 month after BrdU administration. Examples of olfactory bulb sections from a control mouse $(\boldsymbol{P})$ and its knock-out littermate ( $(\mathbf{)})$ injected with BrdU at 2 months of age and killed at 3 months. Arrowheads indicate examples of $\mathrm{PG}$ neurons. Images were identically captured and optimized. Bar graph summarizes quantification of BrdU-positive PG and GL neurons in 3- and 7-month-old mice. Numbers in bars indicate the number of knock-out-control pairs quantified. $\boldsymbol{R}-\boldsymbol{T}$, hGFAP-Cre leads to floxed gene excision in TH ${ }^{+}$PGL cells. GFP reporter signal (green) in $\mathrm{TH}^{+}$(red) PG neurons of hGFAP-Cre ${ }^{+} /$CAG-CAT-EGFP reporter-positive mouse. $\boldsymbol{T}$, Merged view. Abbreviations as in Figure $1 . S$ Scale bars: $\boldsymbol{B}, \boldsymbol{D}, \boldsymbol{H}, 20 \mu \mathrm{m} ; \boldsymbol{F}, 10 \mu \mathrm{m} ; \boldsymbol{I}-\boldsymbol{L}$, $20 \mu \mathrm{m} ; \mathbf{M}-\mathbf{0}, 10 \mu \mathrm{m} ; \boldsymbol{P}, \mathbf{Q}, 50 \mu \mathrm{m} ; \boldsymbol{R}-\boldsymbol{T}, 5 \mu \mathrm{m}$. 

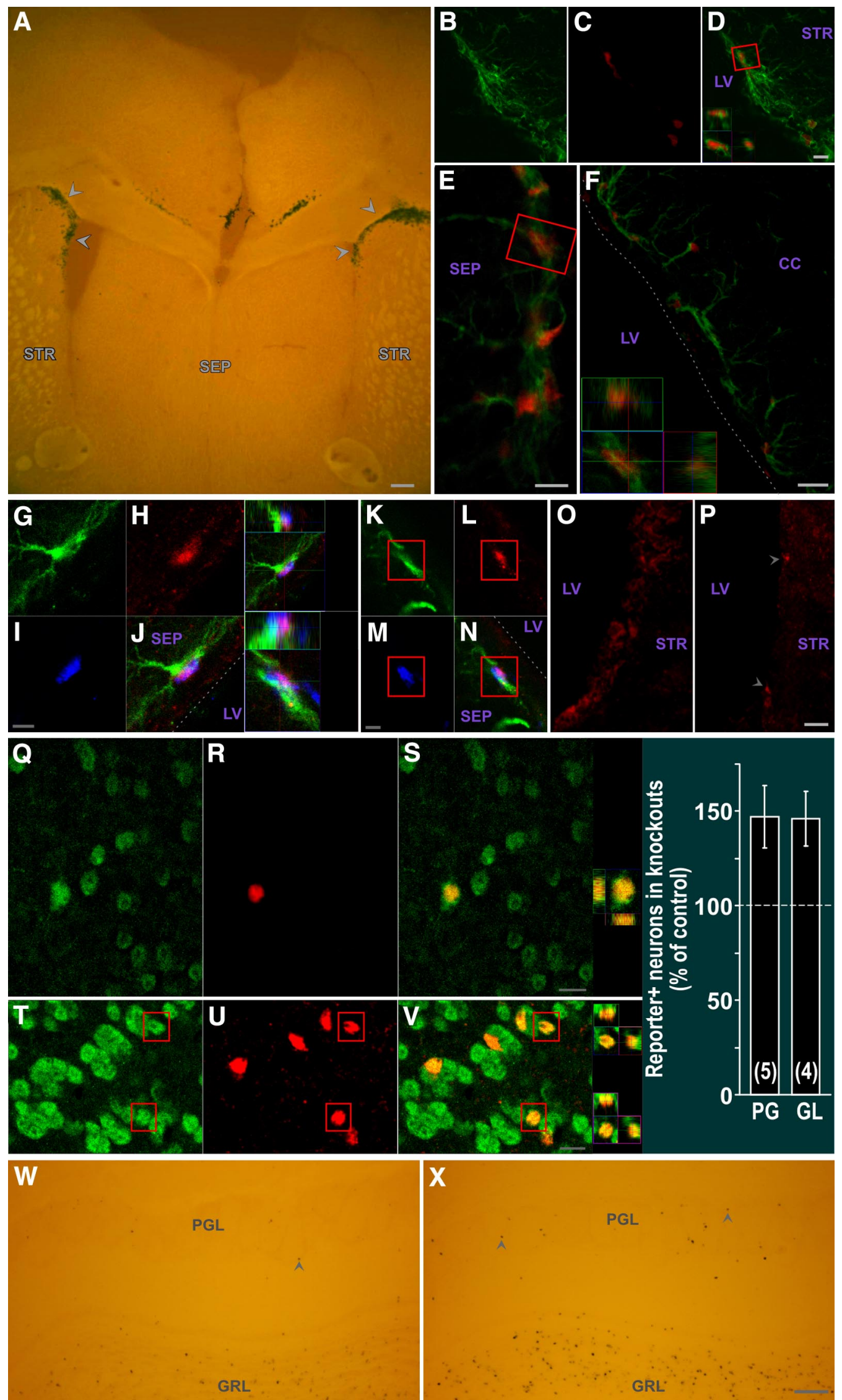

Figure 7. AAV-Cre infection of adult SVZ leads to floxed gene excision in SVZ type B stem cells as well as SVZ CNTFR $\alpha$ depletion and increased olfactory bulb neurogenesis in floxed CNTFR $\alpha$ mice. $\boldsymbol{A}, \mathrm{X}$-gal (dark blue) reporter signal and autofluorescent pseudo "counterstain" showing a high density of Xgal ${ }^{+}$SVZ cells (arrowheads). B-D, Cre (red) expression in GFAP ${ }^{+}$(green) SVZ cells. $\boldsymbol{D}$, Merged view. Boxed cell shown as 3D view in $\boldsymbol{D}$. E, $\boldsymbol{F}$, Floxed gene excision in $\mathrm{GFAP}^{+}$SVZ cells. $\beta$ Gal reporter signal (red) in GFAP ${ }^{+}$(green) cells of $(\boldsymbol{E})$ septal and $(\boldsymbol{F})($ Figure legend continues.) 


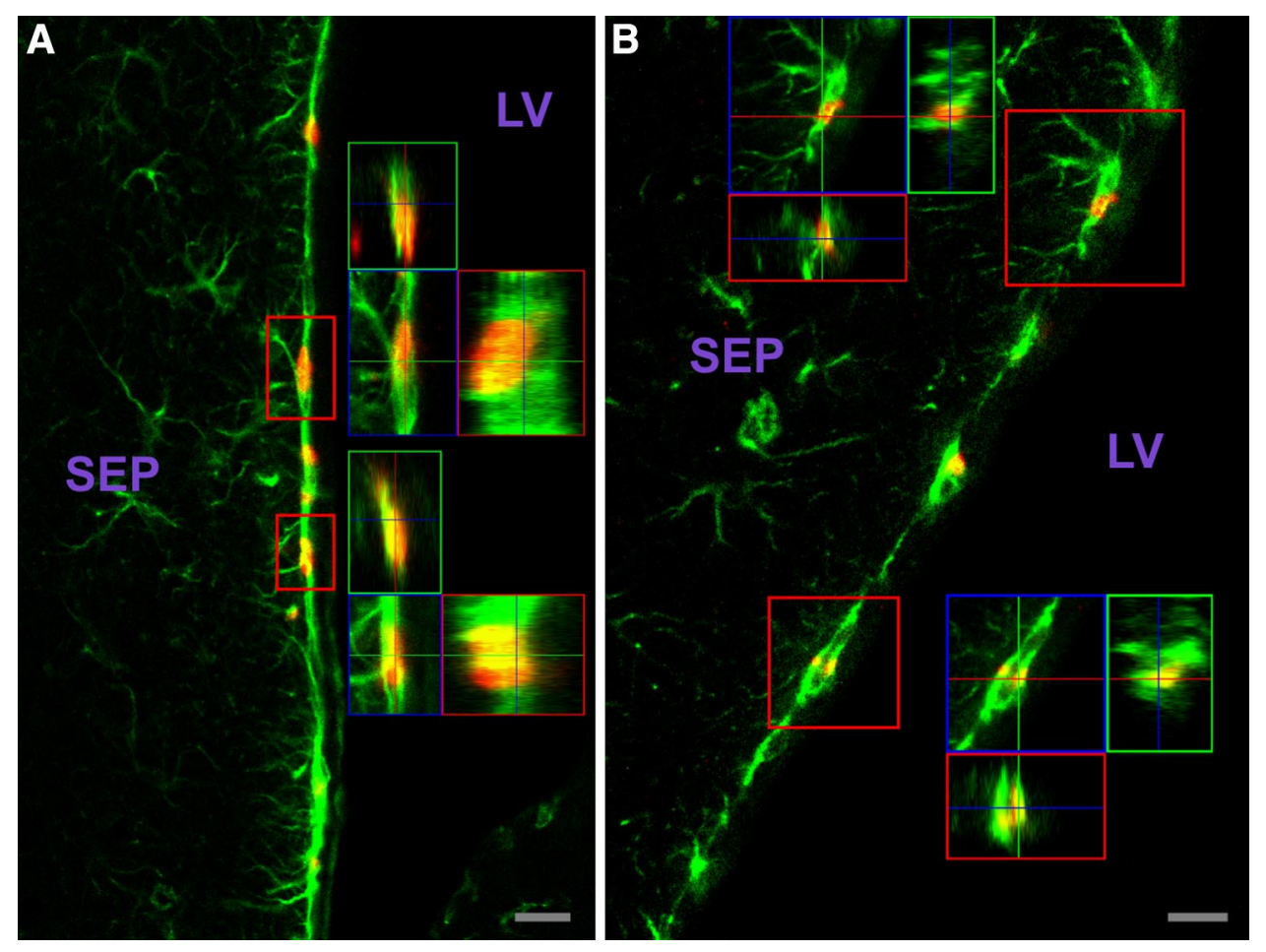

Figure 8. Type B stem cells in septal SVZ can be accurately quantified. Examples in $A$ and $B$ of GFAP ${ }^{+}$(green) septal SVZ cells that retain BrdU (red) administered 1 month before death and display type B cell morphology (few primary processes emanating from soma). In most cases, these prominent processes run parallel with, and overlap, those of neighboring GFAP ${ }^{+}$cells. $3 \mathrm{D}$ views of boxed cells shown. Abbreviations as in Figure 1. Scale bars, $10 \mu \mathrm{m}$.

This result likely, at least in part, derives from increased type B cell proliferation in the knock-outs associated with the increased neurogenesis. Regardless, the data do not indicate any loss of type B cells. Therefore, these data, along with the medial/septal SVZ analysis of BrdU-retaining cells with few primary processes, suggest that CNTF receptor signaling is not essential for the maintenance of type B cells in vivo.

\section{Discussion}

We report that in the adult SVZ, in vivo, functional CNTF receptors that signal through STAT3 are present in type B stem cells. In contrast, they are absent from type A cell neuroblasts and rarely, if ever, present in type $\mathrm{C}$ transit-amplifying cells. We find this

(Figure legend continued.) corpus callosum SVZ. 3D view of cell boxed in $\boldsymbol{E}$ is shown in $\boldsymbol{F}$. Dotted line indicates approximate edge of tissue. $\mathbf{G}-\boldsymbol{N}$, Floxed gene excision in type B stem cells. $\beta G a l$ reporter signal (red) is detected in GFAP ${ }^{+}$(green) SVZ cells with few primary processes that also label with BrdU (blue) administered 1 month before death. 3D views of triple-labeled cells are presented. Dotted lines delineate approximate edge of tissue. $\mathbf{O}, \boldsymbol{P}, \mathrm{AAV}$-Cre infection of SVZ of floxed CNTFR $\alpha$ mice leads to depletion of CNTFR $\alpha$. CNTFR $\alpha$ immunohistochemistry examples of infected SVZ regions of control $(\boldsymbol{O})$ and floxed CNTFR $\alpha(\boldsymbol{P})$ mice. $\boldsymbol{P}$, Arrowheads indicate examples of rare cells with CNTFR $\alpha$. $\mathbf{Q}-\boldsymbol{V}$, Multilable 3D confocal data from AAV-Creinjected ROSA26 reporter mice indicate that essentially all resulting reporter-positive PG and GL cells are $\mathrm{NeuN}^{+}$neurons. Examples of $\beta G$ al reporter signal (red) in NeuN ${ }^{+}$(green) PG (Q-S) and $G \mathrm{~L}(\boldsymbol{T}-\boldsymbol{V})$ neurons, with 3D views of boxed neurons. $\boldsymbol{W}, \boldsymbol{X}$, AAV-Cre infected floxed CNTFR $\alpha$ "knock-out" mice display significantly increased neurogenesis relative to identically treated littermate controls injected and processed in parallel (see text for statistics). Examples of ROSA26 reporter ${ }^{+}\left(\mathrm{Xgal}^{+}\right)$cells in the granular layer (GRL) and PG layer (PGL) of a control mouse $(\boldsymbol{W})$ and its floxed (NTFR $\alpha$ littermate $(\boldsymbol{X})$. X-gal (dark blue) reporter signal and autofluorescent pseudo "counterstain" are shown. Arrowheads designate examples of PG neurons. Images were identically captured and optimized. Bar graph summarizes quantification of reporter-positive PG and GL neurons. Numbers in bars indicate the number of knock-outcontrol pairs quantified. Abbreviations as in Figure 1. Scale bars: $\boldsymbol{A}, 50 \mu \mathrm{m} ; \boldsymbol{B}-\boldsymbol{D}, 10 \mu \mathrm{m} ; \boldsymbol{E}, 5$ $\mu \mathrm{m} ; \boldsymbol{F}, 10 \mu \mathrm{m} ; \boldsymbol{G}-\mathbf{N}, 5 \mu \mathrm{m} ; \mathbf{O}, \boldsymbol{P}, 10 \mu \mathrm{m} ; \mathbf{Q}-\mathbf{S}, 5 \mu \mathrm{m} ; \boldsymbol{T}-\boldsymbol{V}, 10 \mu \mathrm{m} ; \boldsymbol{W}, \boldsymbol{X}, 100 \mu \mathrm{m}$. same cell type-specific expression pattern with CNTFR $\alpha$. Therefore, CNTF receptors are confined to type B stem cells in the adult neurogenic niche.

To conditionally deplete these receptors in vivo, we crossed floxed CNTFR $\alpha$ and hGFAP-Cre mice and confirmed that this manipulation disrupts SVZ CNTF receptors. This disruption leads to larger adult neuroblast populations and increases the adult production of olfactory bulb PG and GL neurons. It also differentially increases olfactory bulb PG neuron subpopulations during adulthood. Adult-onset disruption of the receptor in type $\mathrm{B}$ cells with an AAV-Cre vector similarly leads to more olfactory bulb neurogenesis.

These indications of increased neurogenesis after CNTF receptor disruption suggest that endogenous CNTF receptor signaling inhibits adult neurogenesis. Given that SVZ CNTF receptors are restricted to type B stem cells, the data further suggest that CNTF receptor signaling inhibits neurogenesis through its effects in these cells. The receptor activity may do so by inhibiting differentiation along the neuronal lineage, as suggested by others based on in vitro work (Shimazaki et al., 2001). However, the greater number of BrdU-retaining cells in the lateral SVZ of the CNTFR $\alpha$ knock-outs raises the additional possibility that the knock-out-induced increase in neurogenesis results, at least in part, from an increase in type B cell proliferation and/or activation from the quiescent state, such that endogenous CNTF receptor signaling inhibits such proliferation and/or activation.

It should also be noted that our data do not entirely exclude the possibility that endogenous CNTF receptor signaling in type $\mathrm{B}$ cells indirectly regulates the properties of the progeny produced by these cells. For instance, type B cell CNTF receptor signaling in vivo could theoretically inhibit neurogenesis by favoring the production of a class of neuroblasts that proliferate or migrate slower. 

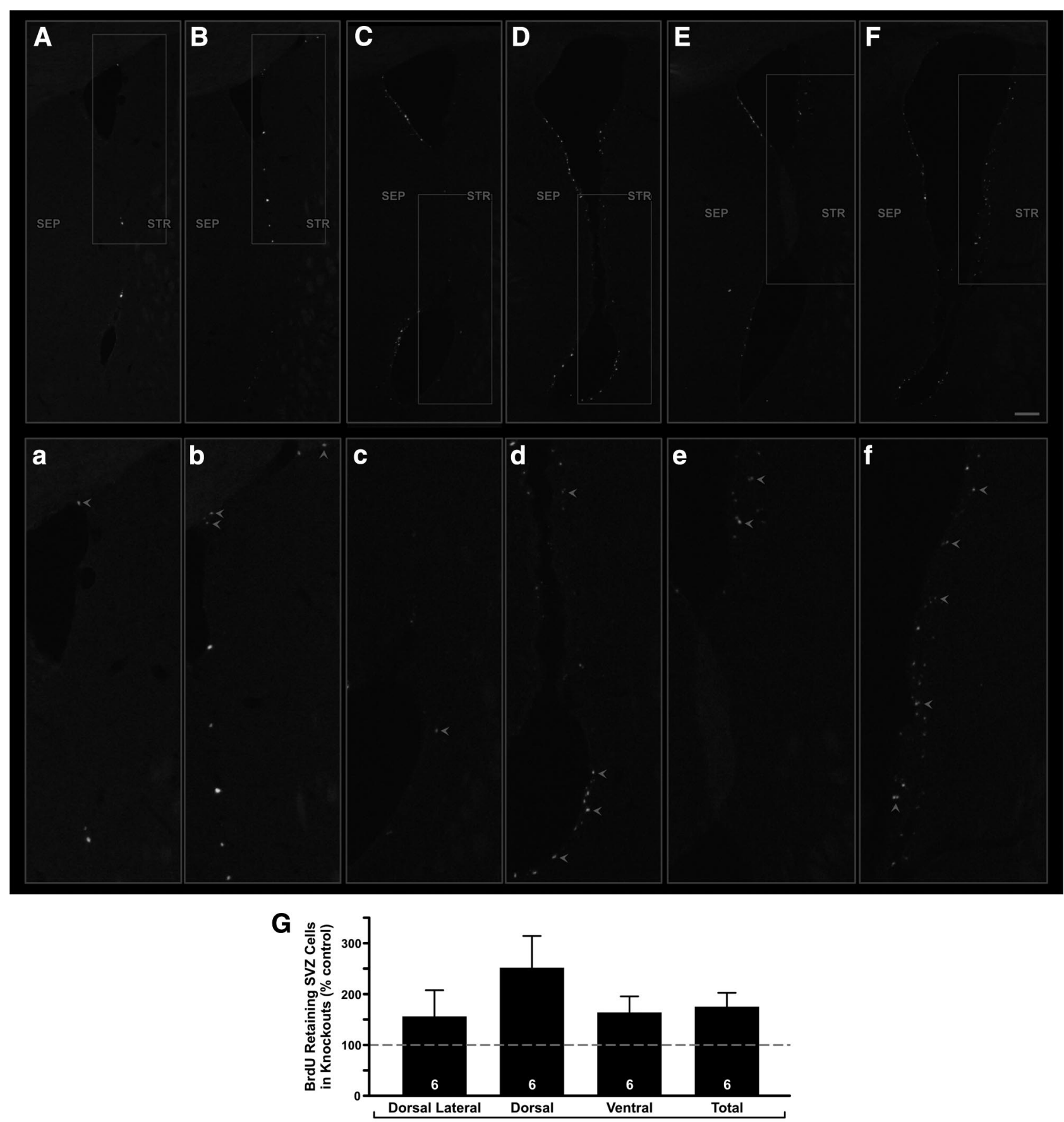

Lateral SVZ Region

Figure 9. CNTF receptor disruption in hGFAP-Cre, floxed CNTFR $\alpha$ "knock-out" mice leads to an increase in BrdU-retaining cells in the lateral SVZ. Sections from an hGFAP-Cre, floxed CNTFR $\alpha$ "knock-out" mouse $(\boldsymbol{B}, \boldsymbol{D}, \boldsymbol{F})$ and a littermate control $(\boldsymbol{A}, \boldsymbol{C}, \boldsymbol{E})$, both injected with BrdU at 6 months of age and processed for BrdU immunohistochemistry at 7 months. Although the number of BrdU-labeled cells in the medial/septal SVZ is not affected by the knock-out, the knock-out mice display significantly more BrdU-labeled cells in the lateral/striatal SVZ relative to their littermate controls. The examples are presented rostral to caudal. Sections were processed free floating and subsequently slide mounted such that the section in $\boldsymbol{E}$ contains some overlapped tissue. $\boldsymbol{a}-\boldsymbol{f}$, Higher-magnification views of boxed regions in $\boldsymbol{A}-\boldsymbol{F}$. Arrowheads indicate examples of BrdU-labeled cells. Scale bar: $\boldsymbol{A}-\boldsymbol{F}, 100 \mu \mathrm{m}$. $\boldsymbol{G}$, Quantification reveals a knock-out-induced increase in BrdU-retaining cells in the lateral SVZ. Dorsal Lateral indicates Dorsal lateral SVZ extension; Dorsal, the remainder of the dorsal half of the lateral SVZ; Ventral, ventral half of the lateral SVZ. The knock-out effects in the individual regions were not statistically significant because of the degree of variability, but ANOVA indicates that the number of cells in the entire lateral SVZ (Total) displayed a significant increase $(p<0.01, F=9.84)$ with no difference between the individual regions $(p>0.05 ; F=1.12)$ and no interaction $(p>0.05 ; F=1.12)$. Number of knock-out-control littermate pairs quantified is indicated in the bars.

Previous in vitro data have suggested that neural stem cell CNTF receptor signaling may promote the self-renewal of adult SVZ stem cells and thereby maintain this population (Shimazaki et al., 2001). However, the present studies did not reveal any nonredundant role for endogenous CNTF receptor signaling in type B cell maintenance. Our quantification of medial SVZ type B cells did not detect a knock-out-induced depletion of these cells. In addition, although other factors can affect neurogenesis, a significant depletion of functional type B cells would most likely produce a detectable decrease in neurogenesis. However, we 
found that the magnitude of the increase in neurogenesis in the knock-outs relative to the controls did not significantly differ between 3 and 7 months of age, despite several months with receptor depletion between these two time points, contrary to what one would expect if CNTF receptors were required to maintain functional type B cells. Moreover, we detect a knock-outinduced increase in BrdU-retaining cells in the lateral SVZ, and therefore again, no evidence of CNTF receptor signaling contributing to the maintenance of stem cells. Interestingly, this increase in BrdU-retaining cells raises the possibility that the apparent increase in type $\mathrm{B}$ cell differentiation along the neuronal lineage (increased neurogenesis) that we observe in the knock-outs is not accompanied by a depletion of type B cells because the type B cell pool is maintained by a compensatory increase in type B cell proliferation and/or activation from the quiescent state. However, given that there are no definitive measures of in vivo type B stem cells, the present data cannot conclusively rule out some contribution of CNTF receptors to type B cell maintenance.

The CNTF receptor disruption increased CB and CR, but not TH, PG neurons. Because adult SVZ CNTF receptors are restricted to type B stem cells, this result raises the possibility that CNTF receptors in these relatively undifferentiated cells may regulate neurogenesis in a neuron subtype-specific manner. Studies suggest that adult-type B stem cells responsible for the generation of individual olfactory bulb neuron classes are present in distinct SVZ regions (Hack et al., 2005; De Marchis et al., 2007; Kohwi et al., 2007; Merkle et al., 2007; Ventura and Goldman, 2007; Young et al., 2007; Brill et al., 2008; Mendoza-Torreblanca et al., 2008; Ihrie et al., 2011). However, given that CNTF receptors are disrupted throughout the SVZ in the CNTFR $\alpha$ knock-outs, as indicated by both the pSTAT3 assay (Fig. 5) and CNTFR $\alpha$ immunohistochemistry (Fig. $6 A-H$ ), it is unlikely that the differential effect of receptor disruption on PG neuron cell types results from hGFAP-Cre failing to affect type B cells destined to generate $\mathrm{TH}$ cells. It is also unlikely that CNTF receptors are selectively expressed in type B cells responsible for CB and CR neuron production but absent from those producing TH neurons because mostly all $\mathrm{GFAP}^{+}$cells throughout the SVZ display CNTFinduced pSTAT3 responses. However, the CNTF receptor effect on type B cell differentiation may depend on the subclass of type $B$ cell involved, such that it plays a nonredundant role in inhibiting neuronal differentiation in those cells generating CB and CR neurons but not in cells generating TH neurons.

The restricted localization of both CNTF and functional CNTF receptors to adult-type $B$ cells suggests that autocrine and/or paracrine CNTF receptor signaling mechanisms may regulate neuronal differentiation of these cells. Most of these CNTF expressing cells can be labeled with acute BrdU administration, further suggesting that CNTF expression may upregulate in active type B cells. The CNTF detected in SVZ ependymal cells, immediately adjacent to type B cells, may reflect paracrine signaling. Alternatively, signaling may occur in the SVZ niche as a whole and could involve other CNTF receptor ligands as well. Furthermore, CNTF mRNA is detected in adult mouse choroid plexus (Galvao et al., 2008), and we observe low levels of CNTF immunoreactivity in the choroid plexus (data not shown), suggesting that this structure may supply CNTF to B cells via CSF. The ependymal layer CNTF immunoreactivity may reflect such signaling. Notably, in vitro work suggests that the adult CSF can affect adult NSP cells (Buddensiek et al., 2010).

Unconditional knock-out of the ligand CNTF leads to decreased adult SVZ neuroblast populations (Yang et al., 2008), although this report does not describe effects on the generation of new neurons. This finding is difficult to interpret in the context of adult neurogenesis because the unconditional knock-out may affect embryonic and/or early postnatal development through disruption of CNTF in NSP cells or other cell types. For example, CNTF receptor signaling has been implicated in embryonic forebrain germinal layer development (Gregg and Weiss, 2005). Clearly, conditional CNTF disruption is required.

STAT3 signaling decreases neuronal differentiation in vitro (Gu et al., 2005; Nagao et al., 2007). CNTF receptors largely signal through STAT3, so it is tempting to speculate that the increase in neurogenesis after CNTF receptor disruption is related to changes in STAT3-based signaling. Decreased Notch signaling, which similarly involves STAT3, also increases adult SVZ neurogenesis in vivo (Androutsellis-Theotokis et al., 2006; Imayoshi et al., 2010). Moreover, Notch and CNTF receptor signaling cross talk in NSP cells in vitro, such that Notch can support NSP cell self-renewing growth in the absence of CNTF, whereas they collaborate to promote gliogenesis and inhibit neurogenesis (Nagao et al., 2007). Together, these findings suggest that Notch signaling may help maintain SVZ stem cell populations in the absence of CNTF receptor signaling in vivo. Notably, blockage of Notch signaling eventually leads to profound decreases in adult SVZ NSC number and neurogenesis (Imayoshi et al., 2010), indicating that CNTF receptor signaling is not able to compensate for this loss.

We found that, whereas $\mathrm{GFAP}^{+} \mathrm{SVZ}$ cells display a robust pSTAT3 response when challenged with $\mathrm{CNTF}$, striatal GFAP ${ }^{+}$ cells fail to respond to even higher amounts of CNTF. These results support other in vivo work indicating that SVZ GFAP ${ }^{+}$ cells are functionally distinct from $\mathrm{GFAP}^{+}$cells found previously (Garcia et al., 2004; Beckervordersandforth et al., 2010). Similarly, our AAV-2 type vector infected GFAP ${ }^{+}$SVZ cells, whereas in other brain regions AAV-2 type vectors infect neurons but not $\mathrm{GFAP}^{+}$cells (Bartlett et al., 1998; Burger et al., 2004). Our data also indicate that these distinctive $\mathrm{GFAP}^{+} \mathrm{SVZ}$ cells are not merely a small subset of the GFAP ${ }^{+}$SVZ cells. Rather, we find that potentially all $\mathrm{GFAP}^{+} \mathrm{SVZ}$ cells respond robustly when challenged with CNTF, and at least a high proportion of the cells are infected with the AAV-2 vector. Therefore, even though active type B cells are a small minority of adult $\mathrm{GFAP}^{+} \mathrm{SVZ}$ cells at any one time point, the remaining $\mathrm{GFAP}^{+} \mathrm{SVZ}$ cells are nevertheless functionally distinct from $\mathrm{GFAP}^{+}$cells in non-neurogenic regions and apparently more similar in many respects to active type $\mathrm{B}$ cells, thereby raising the possibility that all $\mathrm{GFAP}^{+} \mathrm{SVZ}$ cells may have the potential to participate in neurogenesis under some conditions.

\section{References}

Altman J, Das GD (1966) Autoradiographic and histological studies of postnatal neurogenesis. I. A longitudinal investigation of the kinetics, migration and transformation of cells incorporating tritiated thymidine in neonate rats, with special reference to postnatal neurogenesis in some brain regions. J Comp Neurol 126:337-389. CrossRef Medline

Alvarez-Buylla A, Garcia-Verdugo JM (2002) Neurogenesis in adult subventricular zone. J Neurosci 22:629-634. Medline

Alvarez-Buylla A, García-Verdugo JM, Tramontin AD (2001) A unified hypothesis on the lineage of neural stem cells. Nat Rev Neurosci 2:287-293. CrossRef Medline

Androutsellis-Theotokis A, Leker RR, Soldner F, Hoeppner DJ, Ravin R, Poser SW, Rueger MA, Bae SK, Kittappa R, McKay RD (2006) Notch signaling regulates stem cell numbers in vitro and in vivo. Nature 442:823826. CrossRef Medline

Bagley J, LaRocca G, Jimenez DA, Urban NN (2007) Adult neurogenesis and specific replacement of interneuron subtypes in the mouse main olfactory bulb. BMC Neurosci 8:92. CrossRef Medline

Bartlett JS, Samulski RJ, McCown TJ (1998) Selective and rapid uptake of 
adeno-associated virus type 2 in brain. Hum Gene Ther 9:1181-1186. CrossRef Medline

Bauer S, Patterson PH (2006) Leukemia inhibitory factor promotes neural stem cell self-renewal in the adult brain. J Neurosci 26:12089-12099. CrossRef Medline

Bazan JF (1990) Structural design and molecular evolution of a cytokine receptor superfamily. Proc Natl Acad Sci U S A 87:6934-6938. CrossRef Medline

Beckervordersandforth R, Tripathi P, Ninkovic J, Bayam E, Lepier A, Stempfhuber B, Kirchhoff F, Hirrlinger J, Haslinger A, Lie DC, Beckers J, Yoder B, Irmler M, Götz M (2010) In vivo fate mapping and expression analysis reveals molecular hallmarks of prospectively isolated adult neural stem cells. Cell Stem Cell 7:744-758. CrossRef Medline

Boulton TG, Zhong Z, Wen Z, Darnell JE Jr, Stahl N, Yancopoulos GD (1995) STAT3 activation by cytokines utilizing gp130 and related transducers involves a secondary modification requiring an $\mathrm{H} 7$-sensitive kinase. Proc Natl Acad Sci U S A 92:6915-6919. CrossRef Medline

Brill MS, Snapyan M, Wohlfrom H, Ninkovic J, Jawerka M, Mastick GS, Ashery-Padan R, Saghatelyan A, Berninger B, Götz M (2008) A Dlx2and Pax6-dependent transcriptional code for periglomerular neuron specification in the adult olfactory bulb. J Neurosci 28:6439-6452. CrossRef Medline

Buddensiek J, Dressel A, Kowalski M, Runge U, Schroeder H, Hermann A, Kirsch M, Storch A, Sabolek M (2010) Cerebrospinal fluid promotes survival and astroglial differentiation of adult human neural progenitor cells but inhibits proliferation and neuronal differentiation. BMC Neurosci 11:48. CrossRef Medline

Burger C, Gorbatyuk OS, Velardo MJ, Peden CS, Williams P, Zolotukhin S, Reier PJ, Mandel RJ, Muzyczka N (2004) Recombinant AAV viral vectors pseudotyped with viral capsids from serotypes 1, 2, and 5 display differential efficiency and cell tropism after delivery to different regions of the central nervous system. Mol Ther 10:302-317. CrossRef Medline

Clatterbuck RE, Price DL, Koliatsos VE (1993) Ciliary neurotrophic factor prevents retrograde neuronal death in the adult central nervous system. Proc Natl Acad Sci U S A 90:2222-2226. Medline

Dale SM, Kuang RZ, Wei X, Varon S (1995) Corticospinal motor neurons in the adult rat: degeneration after intracortical axotomy and protection by ciliary neurotrophic factor (CNTF). Exp Neurol 135:67-73. CrossRef Medline

Davis S, Aldrich TH, Valenzuela DM, Wong VV, Furth ME, Squinto SP, Yancopoulos GD (1991) The receptor for ciliary neurotrophic factor. Science 253:59-63. CrossRef Medline

Davis S, Aldrich TH, Stahl N, Pan L, Taga T, Kishimoto T, Ip NY, Yancopoulos GD (1993) LIFR $\beta$ and gp130 as heterodimerizing signal transducers of the tripartite CNTF receptor. Science 260:1805-1808. CrossRef Medline

DeChiara TM, Vejsada R, Poueymirou WT, Acheson A, Suri C, Conover JC, Friedman B, McClain J, Pan L, Stahl N, Ip NY, Yancopoulos GD (1995) Mice lacking the CNTF receptor, unlike mice lacking CNTF, exhibit profound motor neuron deficits at birth. Cell 83:313-322. CrossRef Medline

De Marchis S, Bovetti S, Carletti B, Hsieh YC, Garzotto D, Peretto P, Fasolo A, Puche AC, Rossi F (2007) Generation of distinct types of periglomerular olfactory bulb interneurons during development and in adult mice: implication for intrinsic properties of the subventricular zone progenitor population. J Neurosci 27:657-664. CrossRef Medline

Doetsch F, Caillé I, Lim DA, García-Verdugo JM, Alvarez-Buylla A (1999) Subventricular zone astrocytes are neural stem cells in the adult mammalian brain. Cell 97:703-716. CrossRef Medline

Doetsch F, Petreanu L, Caille I, García-Verdugo J-M, Alvarez-Buylla A (2002) EGF converts transit-amplifying neurogenic precursors in the adult brain into multipotent stem cells. Neuron 36:1021-1034. CrossRef Medline

Elson GC, Lelièvre E, Guillet C, Chevalier S, Plun-Favreau H, Froger J, Suard I, Benoit de Coignac AB, Delneste Y, Bonnefoy JY, Gauchat JF, Gascan H (2000) CLF associates with CLC to form a functional heteromeric ligand for the CNTF receptor complex. Nat Neurosci 3:867-872. CrossRef Medline

Emsley JG, Hagg T (2003) Endogenous and exogenous ciliary neurotrophic factor enhances forebrain neurogenesis in adult mice. Exp Neurol 183: 298-310. CrossRef Medline

Enwere E, Shingo T, Gregg C, Fujikawa H, Ohta S, Weiss S (2004) Aging results in reduced epidermal growth factor receptor signaling, diminished olfactory neurogenesis, and deficits in fine olfactory discrimination. J Neurosci 24:8354-8365. CrossRef Medline

Galvão RP, Garcia-Verdugo JM, Alvarez-Buylla A (2008) Brain-derived neurotrophic factor signaling does not stimulate subventricular zone neurogenesis in adult mice and rats. J Neurosci 28:13368-13383. CrossRef Medline

Garcia AD, Doan NB, Imura T, Bush TG, Sofroniew MV (2004) GFAPexpressing progenitors are the principal source of constitutive neurogenesis in adult mouse forebrain. Nat Neurosci 7:1233-1241. CrossRef Medline

Gregg C, Weiss S (2005) CNTF/LIF/gp130 receptor complex signaling maintains a VZ percursor differentiation gradient in the developing ventral forebrain. Development 132:565-578. CrossRef Medline

Gu F, Hata R, Ma YJ, Tanaka J, Mitsuda N, Kumon Y, Hanakawa Y, Hashimoto K, Nakajima K, Sakanaka M (2005) Suppression of Stat3 promotes neurogenesis in cultured neural stem cells. J Neurosci Res 81: 163-171. CrossRef Medline

Hack MA, Saghatelyan A, de Chevigny A, Pfeifer A, Ashery-Padan R, Lledo PM, Götz M (2005) Neuronal fate determinants of adult olfactory bulb neurogenesis. Nat Neurosci 8:865-872. CrossRef Medline

Henry RA, Hughes SM, Connor B (2007) AAV-mediated delivery of BDNF augments neurogenesis in the normal and quinolinic acid-lesioned adult rat brain. Eur J Neurosci 25:3513-3525. CrossRef Medline

Ihrie RA, Shah JK, Harwell CC, Levine JH, Guinto CD, Lezameta M, Kriegstein AR, Alvarez-Buylla A (2011) Persistent sonic hedgehog signaling in adult brain determines neural stem cell positional identity. Neuron 71:250-262. CrossRef Medline

Imayoshi I, Sakamoto M, Yamaguchi M, Mori K, Kageyama R (2010) Essential roles of notch signaling in maintenance of neural stem cells in developing and adult brains. J Neurosci 30:3489-3498. CrossRef Medline

Imura T, Kornblum HI, Sofroniew MV (2003) The predominant neural stem cell isolated from postnatal and adult forebrain but not early embryonic forebrain expresses GFAP. J Neurosci 23:2824-2832. Medline

Ip NY, Yancopoulos GD (1996) The neurotrophins and CNTF: two families of collaborative neurotrophic factors. Annu Rev Neurosci 19:491-515. CrossRef Medline

Ip NY, Nye SH, Boulton TG, Davis S, Taga T, Li Y, Birren SJ, Yasukawa K, Kishimoto T, Anderson DJ (1992) CNTF and LIF act on neuronal cells via shared signaling pathways that involve IL-6 signal transducing receptor component gp130. Cell 69:1121-1132. CrossRef Medline

Ip NY, McClain J, Barrezueta NX, Aldrich TH, Pan L, Li Y, Wiegand SJ, Friedman B, Davis S, Yancopoulos GD (1993) The $\alpha$ component of the CNTF receptor is required for signaling and defines potential CNTF targets in the adult and during development. Neuron 10:89-102. CrossRef Medline

Kim EJ, Ables JL, Dickel LK, Eisch AJ, Johnson JE (2011) Ascl1 (Mash1) defines cells with long-term neurogenic potential in subgranular and subventricular zones in adult mouse brain. PLoS One. 31:e18472. CrossRef Medline

Kohwi M, Petryniak MA, Long JE, Ekker M, Obata K, Yanagawa Y, Rubenstein JL, Alvarez-Buylla A (2007) A subpopulation of olfactory bulb GABAergic interneurons is derived from Emx1- and Dlx5/6-expressing progenitors. J Neurosci 27:6878-6891. CrossRef Medline

Laywell ED, Rakic P, Kukekov VG, Holland EC, Steindler DA (2000) Identification of a multipotent astrocytic stem cell in the immature and adult mouse brain. Proc Natl Acad Sci U S A 97:13883-13888. CrossRef Medline

Lee N, Robitz R, Zurbrugg RJ, Karpman AM, Mahler AM, Cronier SA, Vesey R, Spearry RP, Zolotukhin S, Maclennan AJ (2008) Conditional, genetic disruption of ciliary neurotrophic factor receptors reveals a role in adult motor neuron survival. Eur J Neurosci 27:2830-2837. CrossRef Medline

Lois C, Alvarez-Buylla A (1994) Long-distance neuronal migration in the adult mammalian brain. Science 264:1145-1148. CrossRef Medline

Luskin MB (1993) Restricted proliferation and migration of postnatally generated neurons derived from the forebrain subventricular zone. Neuron 11:173-189. CrossRef Medline

MacLennan AJ, Vinson EN, Marks L, McLaurin DL, Pfeifer M, Lee N (1996) Immunohistochemical localization of ciliary neurotrophic factor receptor $\alpha$ expression in the rat nervous system. J Neurosci 16:621-630. Medline

MacLennan AJ, Neitzel KL, Devlin BK, Garcia J, Hauptman GA, Gloaguen I, Di Marco A, Laufer R, Lee N (2000) In vivo localization and character- 
ization of functional ciliary neurotrophic factor receptors which utilize JAK-STAT signaling. Neuroscience 99:761-772. CrossRef Medline

Malatesta P, Hack MA, Hartfuss E, Kettenmann H, Klinkert W, Kirchhoff F, Götz M (2003) Neuronal or glial progeny: regional differences in radial glia fate. Neuron 37:751-764. CrossRef Medline

Mendoza-Torreblanca JG, Martínez-Martínez E, Tapia-Rodríguez M, Ramírez-Hernández R, Gutiérrez-Ospina G (2008) The rostral migratory stream is a neurogenic niche that predominantly engenders periglomerular cells: in vivo evidence in the adult rat brain. Neurosci Res 60:289299. CrossRef Medline

Merkle FT, Tramontin AD, García-Verdugo JM, Alvarez-Buylla A (2004) Radial glia give rise to adult neural stem cells in the subventricular zone. Proc Natl Acad Sci U S A 101:17528-17532. CrossRef Medline

Merkle FT, Mirzadeh Z, Alvarez-Buylla A (2007) Mosaic organization of neural stem cells in the adult brain. Science 317:381-384. CrossRef Medline

Morshead CM, Garcia AD, Sofroniew MV, van Der Kooy D (2003) The ablation of glial fibrillary acidic protein-positive cells from the adult central nervous system results in the loss of forebrain neural stem cells but not retinal stem cells. Eur J Neurosci 18:76-84. CrossRef Medline

Müller S, Chakrapani BP, Schwegler H, Hofmann HD, Kirsch M (2009) Neurogenesis in the dentate gyrus depends on CNTF and STAT3 signaling. Stem Cells 27:431-441. CrossRef Medline

Nagao M, Sugimori M, Nakafuku M (2007) Cross talk between notch and growth factor/cytokine signaling pathways in neural stem cells. Mol Cell Biol 27:3982-3994. CrossRef Medline

Nakamura T, Colbert MC, Robbins J (2006) Neural crest cells retain multipotential characteristics in the developing valves and label the cardiac conduction system. Circ Res 98:1547-1554. CrossRef Medline

Ninkovic J, Mori T, Götz M (2007) Distinct modes of neuron addition in adult mouse neurogenesis. J Neurosci 27:10906-10911. CrossRef Medline

Pastrana E, Cheng LC, Doetsch F (2009) Simultaneous prospective purification of adult subventricular zone neural stem cells and their progeny. Proc Natl Acad Sci U S A 106:6387-6392. CrossRef Medline

Petreanu L, Alvarez-Buylla A (2002) Maturation and death of adult- born olfactory bulb granule neurons: role of olfaction. J Neurosci 22:6106-6113. Medline

Pitman M, Emery B, Binder M, Wang S, Butzkueven H, Kilpatrick TJ (2004) LIF receptor signaling modulates neural stem cell renewal. Mol Cell Neurosci 27:255-266. CrossRef Medline

Saggio I, Gloaguen I, Poiana G, Laufer R (1995) CNTF variants with increased biological potency and receptor selectivity define a functional site of receptor interaction. EMBO J 14:3045-3054. Medline

Shimazaki T, Shingo T, Weiss S (2001) The ciliary neurotrophic factor/ leukemia inhibitory factor/gp130 receptor complex operates in the maintenance of mammalian forebrain neural stem cells. J Neurosci 21:7642-7653. Medline

Slotnick BM, Leonard CM (1975) A stereotaxic atlas of the albino mouse forebrain, Ex-Lib edition. Washington DC: U.S. Department of Health \& Human Services.

Soriano P (1999) Generalized lacZ expression with the ROSA26 Cre reporter strain. Nat Genet 21:70-71. CrossRef Medline

Taupin P (2007) Adult neural stem cells: the promise of the future. Neuropsychiatr Dis Treat 3:753-760. CrossRef Medline

Ventura RE, Goldman JE (2007) Dorsal radial glia generate olfactory bulb interneurons in the postnatal murine brain. J Neurosci 27:4297-4302. CrossRef Medline

Wu P, Ye Y, Svendsen CN (2002) Transduction of human neural progenitor cells using recombinant adeno-associated viral vectors. Gene Ther 9:245255. CrossRef Medline

Yang P, Arnold SA, Habas A, Hetman M, Hagg T (2008) Ciliary neurotrophic factor mediates dopamine D2 receptor-induced CNS neurogenesis in adult mice. J Neurosci 28:2231-2241. CrossRef Medline

Young KM, Fogarty M, Kessaris N, Richardson WD (2007) Subventricular zone stem cells are heterogeneous with respect to their embryonic origins and neurogenic fates in the adult olfactory bulb. J Neurosci 27:8286-8296. CrossRef Medline

Zhao C, Deng W, Gage FH (2008) Mechanisms and functional implications of adult neurogenesis. Cell 132:645-660. CrossRef Medline

Zhuo L, Theis M, Alvarez-Maya I, Brenner M, Willecke K, Messing A (2001) hGFAP-cre transgenic mice for manipulation of glial and neuronal function in vivo. Genesis 31:85-94. CrossRef Medline 